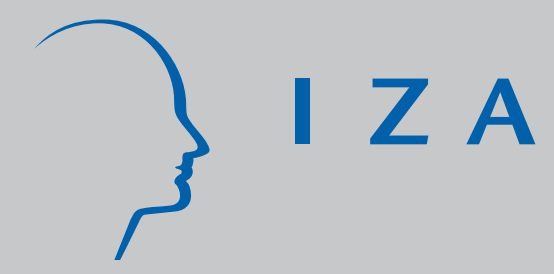

IZADP No. 2215

The German Labor Market:

Still Adjusting Badly?

Werner Eichhorst

Lutz C. Kaiser

July 2006 


\title{
The German Labor Market: Still Adjusting Badly?
}

\author{
Werner Eichhorst \\ IZA Bonn
}

Lutz C. Kaiser

IZA Bonn, DIW Berlin and EPAG

Discussion Paper No. 2215 July 2006

IZA

P.O. Box 7240

53072 Bonn

Germany

Phone: +49-228-3894-0

Fax: +49-228-3894-180

Email: iza@iza.org

Any opinions expressed here are those of the author(s) and not those of the institute. Research disseminated by IZA may include views on policy, but the institute itself takes no institutional policy positions.

The Institute for the Study of Labor (IZA) in Bonn is a local and virtual international research center and a place of communication between science, politics and business. IZA is an independent nonprofit company supported by Deutsche Post World Net. The center is associated with the University of Bonn and offers a stimulating research environment through its research networks, research support, and visitors and doctoral programs. IZA engages in (i) original and internationally competitive research in all fields of labor economics, (ii) development of policy concepts, and (iii) dissemination of research results and concepts to the interested public.

IZA Discussion Papers often represent preliminary work and are circulated to encourage discussion. Citation of such a paper should account for its provisional character. A revised version may be available directly from the author. 


\section{ABSTRACT}

\section{The German Labor Market: Still Adjusting Badly?*}

In the late nineties, Germany was often seen as a laggard with respect to labor market and welfare state reforms with institutional inertia being reflected in notoriously sluggish employment growth and rising unemployment. Recent years, however, saw a complex sequence of reforms with regard to labor market-related institutions such as labor market regulation, social benefits, active and activating labor market policies and attempts to reduce the burden of payroll taxes and - last but not least - a series of changes in collective bargaining. The paper shows if and to what extent labor-market related reforms in Germany have in fact contributed to overcoming structural weaknesses of a Continental European 'welfare state without work' and creating an institutional setup more conducive to strong employment growth and lower unemployment. We provide a detailed institutional analysis of the most relevant reforms in both public policies and collective bargaining and evaluate their effects on labor market structures and dynamics that can be identified so far. In particular we focus on the development of different types of employment and raise the question whether these upcoming non-standard forms of employment may be sustainable with respect to the future of the German labor market.

JEL Classification: J32, J68

Keywords: Germany, labor market policy, labor market reforms

Corresponding author:

Werner Eichhorst

IZA

P.O. Box 7240

D-53072 Bonn

Germany

E-mail: eichhorst@iza.org

\footnotetext{
* We are grateful to Deniz Ortac and Ute Zweers for indispensable research assistance and to participants of a workshop at SASE 2006 in Trier for helpful comments.
} 


\section{I ntroduction}

German labor market problems and the difficulties of institutional reforms have been a notorious topic for political and academic debate in recent years. However, while the notion of reform deadlock was most prominent in the second half of the nineties, there was intense reform activity in the early years of this decade. This inspired both more optimistic and skeptical assessments of reforms and reform capacities in Germany (Economist 2005, 2006, Brandt/Burniaux/Duval 2005, OECD 2006a). On the one hand, observers point at the growing flexibility and regained competitiveness of the German economy. On the other hand, a sequence of labor market reforms - the Hartz and Agenda 2010 packages - raised considerable public and academic attention as well as high expectations both in Germany and abroad. Yet unemployment is still very high in historical terms, while employment growth is sluggish (see figure 1).

--- insert figure 1 here ---

How can this be interpreted? Is it just because reforms need some time to show the desired effects? Or is the German labor market still adjusting badly (Manow/Seils 2000) despite the most recent reforms which might have been overrated and did not contribute to solving the major problems of the German employment system? To find an answer, the paper will first clarify the role of labor market institutions in Continental European welfare state institutions in determining labor market outcomes and discuss the political logic of institutional reforms. The next section provides an up-to-date account of major changes in labor market-related policy areas over the last decade with a focus on the widely debated Hartz and Agenda 2010 reforms before assessing the effects of these reforms with respect to the structure and dynamics of employment and unemployment in Germany. We conclude with some reflections on the reform capacities of the German system and an outlook into the nearer future. 


\section{Reforming A Continental European Labor Market: Why and How?}

Germany fits into established typologies of welfare states and national employment systems as is may be the best example of both a Conservative welfare state (Esping-Andersen 1990) and a coordinated market economy in the sense of Hall and Soskice (2001) conducive to diversified quality production (Streeck 1997). Regarding the labor market, stylized facts are a high level of intra-firm flexibility and high productivity work places in manufacturing. Competitive industrial production is facilitated and stabilized by an elaborate system of vocational training, co-determination, industry-wide collective bargaining as well as by status and skills-protecting employment regulation and a high level of unemployment compensation (Estevez-Abe/Iversen/Soskice 2001).

The manufacturing-based German production model, however, has been encountering major difficulties since the mid-seventies with a more difficult economic environment and fundamental societal changes. Whereas institutional preconditions are conducive to manufacturing in larger firms, the German employment system is ill equipped for the transformation to a service economy which is most crucial as employment in manufacturing is on a long-term decline with future employment growth only to be expected from services. Part of this adjustment problem is due to routine policy responses in the eighties and nineties (Manow/Seils 2000). In order to adjust to the slowdown in economic growth German policy makers tried to keep unemployment down by reducing labor supply. This was achieved through an expansion of benefits in unemployment insurance, early retirement and a rather passive use of active labor market policies. With the economic crisis after reunification also being coped with by another phase of labor supply reduction, this resulted in a significant increase in non-wage labor costs as high benefit dependency automatically results in a higher burden of contributions in the German social insurance system (Scharpf 1997, Manow/Seils 2000).

This is particularly harmful to employment in non-tradable services which is a field of potential future employment expansion. Hence, whereas the German system is conducive to high productivity and competitiveness in manufacturing, it is less capable of achieving a high level of employment in services. This also means that the core of the labor market represented by prime-aged men is stabilized at the expense of labor market access of women, low-skilled and older workers.

Continental European "welfare states without work" (EspingAndersen 1996) therefore risk their own sustainability as the gen- 
eration of resources is tied to labor while not providing the institutional prerequisites for employment stability or growth through service sector jobs. To reduce the burden of benefit dependency, opening up employment opportunities in services and a less selective pattern of access to employment is crucial. However, a higher level of labor market participation and stronger service employment means departure from a "low activity, low inequality equilibrium" to a system that allows for more differentiation and flexibility in the employment system as major segments of services cannot be organized in the same way as manufacturing. This implies changes in the overall labor market and welfare state regime by easing labor market regulation, allowing for more flexible wages, an overhaul of active and passive labor market policies and a reconsideration of welfare state funding via contributions in order to make the institutional arrangement more employment-friendly.

Reforms of labor markets and social policies might be straightforward in economic terms: However, they can be highly problematic with respect to societal acceptance and politico-economic feasibility as gains and losses are distributed unequally over time and people. Given the fact that gains from reforms are certain and will arise at some point in the future whereas losses stemming from interventions into the institutional status quo are often clearer and more concentrated, political actors have to take potential opposition from organized interest groups or the electorate into account if they are not willing to risk losing political power. As introducing a higher degree of external flexibility into the labor market would mean a loss in employment and income securities of labor market insiders, opposition from their side is most probable.

Reform capacities are therefore crucial in determining the options available to policy makers. And welfare state and labor market reforms are more feasible in political terms as well as more effective in economic terms if reforms in different policy areas are complementary to each other (OECD 2006b). Complementary reforms are more acceptable if they can provide for compensation for losses encountered by major societal groups in one area. They are more effective than isolated reforms to the extent that reforms in one policy area take changes in other fields into account (Orszag/Snower 1998).

This is particularly important in Continental European settings where the need for reform is not concentrated in one area but related to several features of the national employment system such as active and passive labor market policies, welfare state funding and employment protection. Hence, recent comparative analysis on labor market and welfare state reforms points at the capacity to manage complementary reforms across policy areas as a core precondition of more successful reform processes (Ebbinghaus/Hassel 
2000, Eichhorst/Konle-Seidl 2005). There are two settings that facilitate complex reform strategies:

1. if government and parliamentary majorities possess the capacity to define and implement a reform strategy without having to take into account opposing majorities in the second chamber of parliament,

2. if government can negotiate broader "package deals" with the social partners given a sufficient infrastructure for tripartite talks and a sufficient level of trust among the actors. However, even in such a setting government's capacity to act unilaterally or threaten to intervene in wage setting or other policy areas can be helpful in furthering social partners' participation in negotiations.

Both alternatives not only depend on actors' capacities to act but also on problem perceptions and political preferences. Even a strong government majority might be unable to implement a coherent reform strategy if the party leadership has no clear vision on these reforms or if the parties are divided with regard to reform necessities and preferred solutions. Hence, the convergence of problem perceptions and the generation of a basic consensus on reforms is essential (Cox 2001).

However, the German political system provides only limited capacities for more far-reaching or complementary reforms as both government capacities are limited in a federalist system with strong autonomy of the social partners and tripartite arrangements not existing at the national level. Given the high consensus requirements and a strong position of labor market insiders with little interest in stronger external flexibility and wage dispersion, since the mideighties this rather resulted in partial reforms at the margin of the labor market with the core remaining relatively untouched and in externalization strategies aiming at reducing labor supply. Thus, policies of the "middle way" and incremental, strongly pathdependent reform are said to be typical for a state characterized by de facto grand coalitions (Schmidt 2001, 2002). This, however, appeared not to be a sufficient response to persistent labor market problems in the mid- to late nineties and was perceived not as an appropriate reform strategy but as reform stalemate.

The remainder of the paper shows which policy reforms were implemented in the German case in core areas such as labor market regulation, labor market policies, taxation and wage setting and how they were formulated in politico-economic terms. This will allow us to assess if the reform sequences of the recent past actually helped Germany overcome reform stalemate and adjust better as compared to the institutional framework that was in place in the late nineties. 


\section{The Fragmented Transformation of the German Labor Market}

Having described the German employment system of the nineties with relatively low employment, increasing unemployment and institutional incentives to exclude low-skilled people, older workers and women from full participation in the labor market, the next section will analyze recent German labor market reforms and then assess if and to what extent they could achieve a more inclusive and flexible labor market. We focus on reforms of labor market institutions, welfare state arrangements and industrial relations. ${ }^{2}$

\subsection{Passive and active labor market policies: the hesitant shift towards activation}

For some decades, labor market policies in Germany were predominantly oriented towards passive income maintenance and reduction of open unemployment through assigning benefit recipients to active labor market policy schemes with job placement and reintegration into gainful employment not being the major priorities. The adjustment process in Eastern Germany after reunification was heavily subsidized through labor market policies (Manow/Seils 2000).

This, in turn, led to increasing fiscal pressures on unemployment insurance and the public budget so that the Kohl government in power until fall 1998 introduced some benefit cuts and increased formal availability and entitlement criteria, e.g. jobseekers were obliged to contact the public employment offices more frequently. However, these changes were revoked by the incoming Red-Green coalition within its approach of reconstructing "social justice". The first period of the Schröder government was characterized by an ad hoc program addressing the young and by experimental pilot projects on better cooperation between the Federal Labor Agency ("Bundesanstalt für Arbeit") taking charge of the short-term unemployed and recipients of unemployment assistance and municipalities responsible for social assistance. With no general consensus on the role of low-wage employment in the service sector, the government opted not for general reforms, but for regional experiments

\footnotetext{
2 See also ZohInhöfer 2004a, 2004b, Eichhorst/Zimmermann 2005, 2006, and Steffen 2006 for even more detailed overviews of reforms in German labor market policies.
} 
with different pilot projects, e.g. the "Mainzer Modell", a scheme subsidizing social insurance contributions of low-wage earners. The overall setup of labor market policies was left untouched although critical assessments of the performance of active labor market policy schemes became available and international experiences in European countries pointed at the crucial role of activation and benefit conditionality, i.e. on making benefit receipt conditional upon accepting job offers or active schemes.

Stability of existing labor market policies came to an end in early 2002 with a report from the Federal Audit Office showing massive misreporting in placement statistics ("Vermittlungsskandal"). This led to the Hartz Commission's report that was presented in August 2002 and provided a blueprint for a complete overhaul of active and passive labor market policies. It aimed at a threefold goal: strengthening job placement and reintegration capacities, activating the unemployed through effective demanding and supporting policies ("Fördern und Fordern") and a partial liberalization of the labor market (see also Jacobi/Kluve 2006).

The core of the Hartz package resulted in major internal restructuring of the "Bundesanstalt für Arbeit" (now: "Bundesagentur"), the introduction of performance-related monitoring in active labor market policies and several new schemes such as a small business start-up grant ("I ch-AG" or Me Inc.) and stronger market-oriented governance through training and placement vouchers, contractingout of services to private providers and temporary agency work for the unemployed ("Personal-Service-Agenturen", PSA). Regarding unemployment benefits, the Hartz reforms left the level of unemployment insurance benefits unchanged, but tightened availability and entitlement criteria and abolished annual adjustments of benefits. Through the supplementary reforms of "Agenda 2010", maximum unemployment insurance benefit duration for older workers was reduced from 32 to 18 months.

The major change, however, was the fourth pillar of the reform package ("Hartz IV"): both earnings-related, but also means-tested unemployment assistance paid after expiry of unemployment insurance benefits and social assistance for employable people were replaced by a flat-rate and means-tested unemployment assistance scheme that does not take prior earnings into account anymore ("Arbeitslosengeld II"). Post-reform unemployment assistance is now fixed at $€ 345$ per month for single adults, $€ 310$ in couples, and $€ 200$ for children. Housing and heating are covered completely if appropriate. This meant that status-protection of the long-term unemployed was abolished in favor of a joint flat-rate benefit for all jobseekers not entitled to unemployment insurance benefit, i.e. with prior employment shorter than the waiting period or after expiry of 
the insurance benefit that lasts up to 18 months as of 2006. However, the unemployed receive a gradually declining supplement once the unemployment insurance benefit expires.

Hartz IV was not only conceived as a measure to reduce benefits for the long-term unemployed with high earnings-related unemployment assistance so as to reduce their reservation wage and increase job search intensity. It also aimed at reducing unemployment duration through a more activating approach based on closer monitoring of the long-term unemployed, strict availability criteria and the creation of new one-stop shops responsible for counseling the jobseekers. However, due to a complex political compromise this resulted in joint bodies of BA and municipalities or in models with sole responsibility of the municipalities in some districts. This implies major problems with regard to effective implementation.

Regarding work incentives, Hartz IV only reduced benefits for some household constellations such as dual earners with relative high unemployment assistance claims while it increased benefits for former social assistance recipients and those recipients of low unemployment assistance who did not apply for supplementary social assistance. Recipients of unemployment assistance, however, can top-up their benefits through earned income. ${ }^{3}$ However, incentives to earn more than the income maximum defined by the earnings disregard clause is weak as marginal taxation reaches 80 to $90 \%$ due to income tax liability and partial withdrawal of the benefit. This leads to virtually stagnant net income in spite of higher earnings or longer working time (OECD 2006). In addition, public employment opportunities ("One-Euro-Jobs") lasting up to six to nine months that are supposed to stabilize "employability" and assess availability for work provide additional net earnings of $€ 1$ to 2 per hour not deducted from benefits.

Hence, from both public employment opportunities and earnings disregard clauses create strong incentives to work part-time and not to search for full-time employment result. Net income from unemployment assistance, in particular if combined with some earned income from part-time work, Minijob or a One-Euro-J ob is close to or higher than market wages, especially in the case of low-skilled persons with spouses and children or lone parents whose potential is limited to low-wage employment in the service sector (Boss/Christensen/Schrader 2005, Cichorek/Koch/Walwei 2005, Brenke 2006).

\footnotetext{
${ }^{3}$ According to the current earnings disregard clause in unemployment assistance, $100 €$ per month can be earned without benefits being reduced. Earnings between 100 and $800 €$ are taxed at a marginal rate of $80 \%$ whereas $90 \%$ of all earnings above $800 €$ are taxed away (up to 1.200 or $1.500 €$ per month).
} 
--- insert table 1 here ---

While activation of the long-term unemployed is at best reluctant in practice, reforms at aiming at a better labor market integration of older workers have also been hesitant and contradictory in recent years. Some early-retirement schemes were terminated and the maximum duration of unemployment insurance benefit cut to 18 months, a step announced in 2003 but effective as of February 2006 only. But incentives to leave the labor market before the statutory retirement age still exist such as old-age part-time work (open until end of 2009) and the option of receiving unemployment insurance benefits or unemployment assistance without being available for work, a provision that was prolonged by the grand coalition until 2007. Early retirement pensions will only be phased out until 2016. Pensions in case of partial disability are regularly granted as full pensions as it is generally assumed that suitable work is not available (Eichhorst 2006, OECD 2006b). On the other hand, specific measures were introduced in order to improve employment perspectives of older workers such as lower employer contributions, liberal provisions regarding fixed-term contracts or a wage protection scheme that provided for an earnings supplement in case jobs with lower earnings are taken up. However, shorter benefit duration of earnings-related unemployment insurance and lower levels of public old-age pensions to be expected by younger cohorts due to the break with status-maintaining old-age pensions by the most recent pension reforms make early exit from the labor market less attractive and will contribute to higher employment of older workers in the medium run.

\subsection{Taxation and social insurance contributions: Increasing the tax-share of welfare state funding}

High non-wage labor costs, in particular social insurance contributions are probably the strongest impediment against employment growth in services. Attempts at lowering them have been a recurrent topic of recent reforms.

On the one hand, the red-green coalition aimed at reducing the burden of non-wage labor costs through an increase in the share of social expenditure financed through taxes. The most prominent step in this direction was the introduction of an additional tax on fuel, gas and electricity in 1999 ("Eco-tax") to keep non-wage labor costs below $40 \%$ of gross wages. Hence, pension contributions could be lowered to $19.1 \%$ in 2001 , but were raised to $19.5 \%$ in 2003 . In 2003, taxes were for the first time used to finance some benefits in 
health insurance, while the principle of parity financing through employers' and employees' contributions was abolished at the same time and specific employee contributions for dentist services were introduced. Additional short-term actions were deemed necessary to stabilize the revenue side of social insurance and limit expenditure increases, e.g. frequent ad hoc pension freezes after 2000, disproportional increases of the wage ceiling relevant for the calculation of contributions, the reduction of the old-age pension fluctuation reserve or the reintroduction of the sustainability factor which will lead to lower annual pension adjustment.

Attempts at stabilization through partial shift to taxes, benefit cuts and additional payments by the insured resulted in a departure from parity of contributions and a creeping privatization of health care through shift of expenditures to insured persons. Hence, the public health insurance moves towards a basic protection system as does the old-age pension system through reduction of pensions for younger people and the introduction of advance-funded private schemes. This may help reduce non-wage labor costs in the medium and long-term perspective. At the same time general tax revenues are more heavily used to subsidize the social security schemes, but also to subsidize private pension schemes. The share of taxes in the funding of social expenditures rose from $33.1 \%$ in 1992 to $37.5 \%$ in 1999 and $39.1 \%$ in 2003 (BMGS 2005). This pattern basically represents a long-term increase in the share of unemployment insurance, active labor market policy and pension, but also health insurance expenditure funded through taxes (Streeck/Trampusch 2005). This trend is amplified further by the Hartz IV reform that results in an even higher share of tax resources used for passive and active labor market policies for the long-term unemployed while the contribution-funded part of expenditures on benefits and active labor market policy schemes declines. ${ }^{4}$

Despite these changes, the burden of non-wage labor could not be eased effectively. At best, these reforms helped stabilize the overall contribution rate to social insurance (see figure 2). A significant reduction of social insurance contributions could not be achieved so far.

--- insert figure 2 here ---

\footnotetext{
${ }^{4}$ In 2005 , BA spent 53,1 billion $€$ on unemployment insurance benefits and active labor market policies for the short-term unemployed, 4.9 billion $€$ less than assumed in the budget, and needed only minimum government deficit coverage of about 400 million $€$, whereas expenditure on unemployment assistance reached 44.3 billion $€$, about 8.2 billion $€$ more than expected.
} 
This, however, is only true for regular employment as part-time jobs below a certain earnings ceiling benefit from lower social insurance contributions rates. So called "marginal jobs" ("geringfügige Beschäftigung") below DM 630 per month were exempt from social insurance and only subject to lump-sum taxation. This model of taxation was replaced by social security contributions for the employer and coverage of marginal employees through social insurance only in 1999 in order to prevent erosion of social insurance revenues. At the same time second jobs using this privilege were ruled out. In 2003, however, they were reintroduced within the context of the Hartz reforms as "Minijobs" so that earnings up to $€ 400$ per month can now be gained without deduction of income taxes and employee contributions, whereas the employer has to pay contributions of $25 \%$, slightly higher than the regular rate, and a lumpsum wage withholding tax $(2 \%) .^{5}$ Minijobs in private households benefit from lower employer contribution rates of only $11.7 \%$ plus $2 \%$ lump-sum tax. At the same time, the working time limit of 15 hours per week was lifted. Tax- and contribution-free Minijobs are particularly attractive for people covered by social insurance through their first job, but also for students, pensioners and second earners in married couples. ${ }^{6}$

On the other hand, while indirect taxes such as the Eco-tax were raised, the red-green coalition implemented significant reductions in direct taxes, i.e. personal income taxes and corporate taxation. Regarding personal income taxes, the red-green coalition increased the basic allowance in several steps while at the same time reducing entry and maximum tax rates so that a considerable reduction of the personal income tax burden could be realized between 1999 and 2004. As a result, the income tax burden of average households decreased by 2 to 5 percentage points (OECD 2005). There was, however, no basic change in joint taxation of married couples which implies strong marginal taxation of the second earners' income if it passes the Minijob threshold of $€ 400$ per month. However, moderate incentives for marketization of services and legalization of shadow economy activities in household-related services were implemented through Minijobs in private households being subject to lower employer contributions and the option to deduct expenditures on household-related services - up to an annual maximum of $€ 510$ in case of Minijob employment and $€ 2.400$ with regular employ-

\footnotetext{
${ }^{5}$ As of July 2006, the employer contribution rate will be raised from 25 to $30 \%$.

${ }^{6}$ Gross earnings between $€ 400$ and 800 per month fall in the segment of so called Midijobs with employee social insurance contributions increasing proportionally with earnings so that they reach the regular rate at the upper threshold. Midijobs are subject to regular personal income taxation.
} 
ment but also two thirds of child care cost up to $€ 4.000$ per child and year - from personal income taxes.

\subsection{Regulation of the labor market: Continuing partial de- regulation}

Referring to the employment protection, reforms were limited to flexible jobs and marginal changes in dismissal protection. On the one hand, we can observe a long-term trend towards progressive flexibility at the margin through easing restrictions on fixed-term contracts and temporary agency work. As in other Continental European countries, flexibilization of the labor market has for a long time been restricted to liberalizing non-standard employment. However, an earlier liberalization of fixed-term contracts by the Christian Democratic-Liberal coalition in 1996 was countered by a more restrictive approach by red-green in 1999 allowing fixed-term contracts with valid reason only in case of newly hired employees. However, the Hartz reforms lowered the age threshold for fixedterm employment to 52, which, combined with the general option of fixed-term contracts without valid reason for up to two years, meant that dismissal protection was neutralized for newly hired older workers. ${ }^{7}$

Temporary agency work, on the hand, was largely liberalized within the Hartz context in order to facilitate job placement via commercial temporary work agencies, abolishing the synchronization ban and maximum placement periods - however the law on fixed-term contracts applies (OECD 2004). In exchange for this deregulating step, the principle of equal treatment of TWA workers and comparable permanent staff was introduced, allowing for deviations only for the first six weeks after hiring of unemployed persons and through collective agreements. So the liberalization of temporary agency work was complemented by the first establishment of collectively agreed wages in this sector. This led to some reduction of the wage differential between regular and temporary employment.

To facilitate job creation through self-employment, particularly within the range of subsidized Me Inc., the red-green coalition aimed at lifting the requirement of having a craftsman's diploma ("Meisterbrief") in order to be allowed to start a business in the crafts professions. Against opposition from the Christian Democrats this was achieved in 53 protected crafts with 41 professions still re-

\footnotetext{
${ }^{7}$ This provision, however, has to be revised as the European Court of Justice, in a judgment from late 2005, saw an unfair discrimination of newly hired older workers as they were excluded from regular dismissal protection.
} 
quiring a craftsman's diploma. This countered the tendency of the early years of restricting self-employment without employees by assuming dependent work if there was only one client ("Scheinselbstständigkeit"). Pseudo self-employed persons were then treated as dependent employees and thus liable to social insurance.

Dismissal protection, finally, was maintained without major changes. The Kohl government's lifting of the size threshold for the application of statutory dismissal protection from 5 to 10 employees and restricting the social selection criteria was revoked in 1999. However, with the policy shift of the Agenda 2010 in 2003, the size threshold was raised to 10 employees for new hirings and social selection criteria narrowed down again. At the same time, dismissed workers were entitled to opt for a minimum severance pay of half a month's salary per year of job tenure if they did not file a lawsuit. In practice, however, this meant additional bargaining power for the employees as they can now threaten the employer to go to court in order to maximize severance pay. If they sign an agreement on the dismissal, they also risk a waiting period in unemployment insurance benefits (Jahn 2005).

\subsection{Wage setting, working time and collective bargaining:}

With regard to wage setting, we cannot see a general change of the industrial relation system but collective bargaining coverage and membership in unions and employers' associations has been declining in recent years. Union density declined from $28.7 \%$ of all workers in 1992 in West Germany to $23.8 \%$ in 2002, whereas in the Eastern Federal States membership went down from $39.7 \%$ to $20.4 \%$. Employers' organization data is scarce but available data show a marked decline in the metalworking sector from about $75 \%$ of all workers employed in organized firms in the late eighties to about $60 \%$ in 2003 in West and $21 \%$ in East Germany (Schnabel 2005). This implies less influence of collective agreements on enterprise-level arrangements regarding working time and wages. Coverage by industry-wide collective agreements went down from $69 \%$ $(56 \%)$ of all workers in 1996 in the West (East) to $62 \%(43 \%)$ in 2003. However, about $16 \%$ of all employees in the West and $24 \%$ in the East work in firms that use a collective agreement as a guideline.

At the same time, however, flexibility inside the system has grown due to wider provision and use of opening clauses and frequent experiences with enterprise-level concession bargaining ("betriebliche Bündnisse", Rehder 2003) in industries where international competition between locations of production has become more intense in recent years. As a consequence, over the last years, both collec- 
tively agreed and effective wages increased only moderately (OECD 2006) with Germany being one of the countries with the lowest level of wage growth and declining unit labor costs.

As with wage setting, working time is mostly influenced by the social partners and enterprise level bargaining. Collective and enterprise-level agreements have allowed for more widespread existence of highly flexible working time arrangements. Between 1993 and 2004 the share of enterprises with flexible working time patterns has increase from 15\% to two thirds (DIHK 2004, OECD 2006b).

Most recent trends in collective agreements and enterprise level bargaining point in the opposite direction with agreed and effective working time growing again. This development was triggered by business aiming at higher competitiveness which could not only be realized by wage cuts but also by longer working hours at given wage levels. Hence, the flexibility within collective and enterprise agreements could be improved with the recent trend towards longer working times contributing to lower unit labor costs. Together with the newly gained flexibility of wage setting, this has strengthened internal flexibility mostly in the manufacturing sector and competitiveness of German industry in global markets.

At the same time, however, working time dualization between men in full-time employment and women mostly working part-time could not be overcome. Incentives in the tax system and labor market regulation such as joint personal income taxation and Minijobs still provide incentives to reduce labor supply of second earners and keep them within a segment of low hours combined with low hourly wages. Growing part-time employment clearly contributed to labor market integration of women, but this is still less than full integration of women. On the other hand, Minijobs provide an additional model of flexible labor input, particularly in the service sector.

Legal interventions in wage setting and working time are rare in Germany. However, in December 2000, the Red-Green government entitled employees to switch from full- to part-time employment if there are no business reasons against this. And in 1999 the government changed the posted workers law which aimed at fixing minimum wages applicable both to German and foreign construction workers and allowed the Minister of Labor to make minimum wage agreements in the construction sector generally binding. Prior to this reform, generally binding collective agreements depended upon the consensus of employers' and trade union peak associations. This led to a subsequent increase in minimum wages in the construction sector as opposition from the employers' peak association was weakened. In the current context of fears of increasing low-wage employment due to stricter activation of the long-term unemployed and employers' option to reduce wages at the low end of the wagescale as they are topped-up by social benefits, the trade unions and 
the Social Democrats consider introducing either a general statutory minimum wage or making collectively agreed minimum wages generally binding through expanding the posted workers law.

\subsection{The Partial Flexibilization of the German Labor Market}

Recent German labor market reforms still show strong path dependency with marginal changes enacted before. Continuity is most pronounced in stable institutions governing regular employment, additional partial reforms of employment protection and the move towards a more tax-financed welfare state through the Eco-tax reform and the growing role of taxes in labor market policy and pension funding. However, recent reforms also questioned the notion of path dependency to the extent that departure from statusprotection towards universal basic protection became a more explicit trait in old-age pension and unemployment assistance.

But stronger activation of the long-term unemployed is not as effective as was expected. Instead of reintegrating long-term unemployed and low-skilled people into the labor market through lowwage entry jobs, the most recent reforms established several models of low-wage employment through the backdoor. This holds for four segments of flexible jobs with low remuneration: Minijobs and Midijobs, One-Euro-Jobs, low-wage part-time work taking earnings disregard or top-up provisions into account, and subsidized smaller start-ups (Me Inc.).

On the one hand, these types of jobs are privileged to the extent that they benefit from subsidization via lower non-wage labor costs or combination with benefit payments. Hence, in comparison to regular employment, particularly in the service sector, they are cheap for employers and attractive for employees. On the other hand, moving from these carefully defined compartments of flexible and low-wage employment to regular employment is difficult as passing crucial earnings thresholds results in high marginal taxation. So, while regular employment is still stabilized through existing welfare state arrangements and benefits from more flexibility in collective bargaining, the overall structure of the German labor market changes as it moves closer to a dual labor market. 


\section{Has the Adjustment Potential of the German Labor Market I ncreased?}

Did the recent reforms contribute to improving the adjustment capacities of the German labor market? Is it possible to detect some progress regarding structural unemployment, benefit dependency and a higher and more equal labor market integration?

Looking at unemployment and employment rates first, we cannot identify significant improvements. While employment counted in heads increased a bit, the total number of hours worked fell by about five percent (figure 3 ).

-.- insert figure 3 here ---

We can still identify a selective pattern of labor market integration although there were some smaller increases in employment of women and older workers (figure 4). Improvements in the labor market integration of older workers, women and the low-skilled are less impressive if we take into account that most of them are employed on a part-time basis. This is true for women that make up $81 \%$ of all part-time workers and $64 \%$ of all Minijob employees. But even the increase in old-age employment rates can be attributed to a major increase in part-time employment (Büttner 2005). Finally, low-skilled workers benefit from the combination of part-time work and transfer payments.

--- insert figure 4 here ---

However, stagnation or stability at the macro-level hides structural changes in the composition of employment as well as of unemployment. If we take broad sectors into account, data shows that employment in the manufacturing sector has been declining for many years while the service sector is growing continuously.

--- insert figure 5 here ---

In recent years, the German manufacturing sector benefited from trade union and employee concessions on wages and working times so that international competitiveness measured by unit labor costs 
was restored. ${ }^{8}$ Wage and working time flexibility helped stabilize the welfare state through the generation of taxes and social security contributions from regular employment which is still dominating German industry. However, concession bargaining only slows down the long-term decline in employment in manufacturing. Future employment growth can only be expected from the service sector.

However, the structural change from manufacturing to service sector employment is associated with a long-term decline of regular employment, i.e. full-time employment with open-ended contracts ("Normalarbeitsverhältnisse", figure 6). While this was only true for the relative share over many years as regular jobs stagnated in absolute terms and the flexible segment provided additional employment opportunities, recent years also show an absolute decline in full-time employment with open-ended contracts. However, while jobs in the shrinking sector of manufacturing are relatively stable, jobs are less stable in services (Hoffmann/Walwei 2003, Erlinghagen/Knuth 2004). Growth is most pronounced in the share of selfemployment, Minijobs and part-time work, whereas fixed-term contracts remained stable.

--- insert figure 6 here ---

This is accentuated by data on the development of employment covered by social insurance and of Minijobs. Between 2000 and early 2006, regular employment covered by social insurance declined by about 2 million whereas employment in Minijobs increased significantly, in particular with regard to the once again legalized second jobs (figure 7).

--- insert figure 7 here ---

Hence, the change in the structure of employment relationships can to some extent be attributed to structural features of the different sectors, but this development is also reinforced by institutional patterns that are set through political decisions, i.e. the relative low labor cost and high flexibility in Minijobs, fixed-term employment, temporary work agencies or subsidized forms of dependent or selfemployment: however, whereas fixed-term employment can be

\footnotetext{
${ }^{8}$ Calculations by the Council of Economic Advisors show that unit labor costs in manufacturing in 2004 were slightly lower than in 1992. An increase in unit labor costs in manufacturing by eight percent between 1992 and 1996 could be reversed over the following years. Unit labor cost grew stronger in services with about $20 \%$ in private and public services and $32 \%$ in business-related services.
} 
seen as a prolonged probationary period, other forms of employment offer limited prospects of mobility to stable jobs and higher remuneration, thereby reinforcing labor market segmentation (Boockmann/Hagen 2005).

With the Hartz reforms being the first labor market policy reforms to be evaluated in a systematic way, preliminary evaluation reports (Bundesregierung 2006, Jacobi/Kluve 2006) show improved internal governance procedures within the BA, better placement activities, systematic profiling of jobseekers and higher effectiveness of some labor market policy schemes to that it is reasonable to argue that labor market policy effectiveness has grown. The departure from long-term training schemes with significant locking-in and questionable employment effects towards shorter training schemes with less locking-in but creaming in favor of better risks is most notable (Kaiser/Rinne/Schneider 2006). This resulted in a decline in stocks of participants in traditional active labor market policy schemes, such as training and direct job creation, while new instruments such as the Me Inc. became increasingly popular (figure 8). However, there have not been significant positive employment effects of active labor market policies for older workers so far (Eichhorst 2006).

--- insert figure 8 here ---

So while expenditures on some schemes could be reduced, new programs that are prone to windfall benefits required additional funding. In general, however, expenditures and participant inflow were reduced after the reform. There is also some evidence that the BA now applies stricter monitoring and sanctioning within the context of unemployment insurance benefit payments, i.e. in the first phase of unemployment (OECD 2004, 2006b, Oschmiansky/Müller 2005). Despite the growth of some schemes this process led to higher transparency of unemployment, with hidden unemployment comprising the unemployed in active in passive schemes declining, and open or registered unemployment increasing (figure 9). ${ }^{9}$

--- insert figure 9 here ---

\footnotetext{
9 The requirement of all former social assistance recipients to register unemployed if they are in principle employable, which was introduced with the Hartz IV reform, can explain the extra rise in registered unemployment by about 350.000 between December 2004 and J anuary 2005.
} 
While the BA could reduce some slack and expenditure on some ineffective labor market policies, there is still a problem of externalization as BA does not provide reintegration services to the potentially long-term unemployed any more. This means that after initial profiling, the unemployed with a high risk of becoming permanently unemployed are neglected until they enter the unemployment assistance system. Unemployment assistance after Hartz, however, is less activating as the demanding elements of the reform are far less stringently implemented as was assumed at the outset.

With benefits available for the long-term unemployed that are close to or in some cases higher than equivalent market wages, activation through monitoring job search, job offers and workfare elements is crucial - however, this is hardly implemented by the responsible bodies. ${ }^{10}$ In contrast, the long-term unemployed take up public employment opportunities ("One-Euro-Jobs") voluntarily to top up their benefits for some time. ${ }^{11}$ About one fifth of all employable recipients of unemployment assistance combine benefit receipt with part-time work through the implicit in-work benefits of the earnings disregard clauses. Combining benefit receipt with public employment opportunities or earned income below the earnings disregard threshold provides net income at low working hours that could hardly be achieved through full-time work in the service sector at low hourly wages. Taking into account relatively high reservation wages of the unemployed due to the generous benefit system for the long-term unemployed (Christensen 2005), this results in low job search intensity. Thus full benefit dependency or partial benefit receipt combined with partial labor market integration via One-Euro-Jobs or earnings top-up are prolonged. Together with take-up rates of unemployment assistance higher than estimated, these developments result in higher benefit dependency (figure 10) and extra expenditure rather than economies (Kaltenborn/Schiwarov 2006). ${ }^{12}$ This

\footnotetext{
${ }^{10}$ A recent report by the Federal Audit Office provided first empirical evidence on reluctant monitoring and activation of the long-term unemployed. Availability for work and neediness are not checked systematically. Average waiting time for the first interview was about three months. About two thirds of all long-term unemployed did not have a strategic job search interview within the first seven months of unemployment assistance payments, and in about half of the cases no reintegration contract was signed, while half of the contracts were not monitored effectively.

${ }^{11}$ One-Euro-jobs are highly attractive to the employers as well since overhead costs are refunded on a lump-sum basis in addition to wages.

12 While the Federal, Länder and municipal level spent 39.1 billion $€$ on unemployment and social assistance for employable people in 2004 and planned to economize about three billion $€$ through the Hartz IV reform, actual expenditure reached 44.3 billion $€$ in 2005 . The budget for 2006 assumes total expenditures of 47.6 billion $€$ but recent estimates suggest actual spending of more than 50 billion $€$.
} 
also means that the share of tax-funded active and passive labor market policies increases.

--- insert figure 10 here -.-

One-Euro-Jobs and jobs to top-up unemployment assistance are only two examples of the increasing segment of flexible employment with low remuneration in Germany. The unexpected emergence of low-wage employment is most pronounced in the segment of Minijobs which grew increasingly popular again after the latest change that raised the earnings threshold, abolished the weekly working hours limit and legalized second jobs without employee contributions again. This contributed to growing Minijob employment in the service sector whereas regular employment declined. However, Minijobs are rarely used by the unemployed or lowskilled. These groups, at whom Minijobs were originally targeted, are crowded out by people with a regular first job, students, spouses and pensioners. As a consequence, low-wage jobs are overrepresented in part-time work with about $85.8 \%$ of all Minijob employees receiving low wages in 2004 , compared to $14.6 \%$ of all full-time employees (Kalina/Weinkopf 2006, Brenke 2006). A significant share of qualified employees gets trapped in low-wage employment by Minijobs. The "encapsulation" of low-wage employment through benefit top-up employment, One-Euro-Jobs and Minijobs with earnings and working time threshold that are hard to pass can also be made responsible for the low upward mobility in the German low-wage sector (Rhein/Gartner/Krug 2005).

Wage patterns that had proved to be relatively stable until the midnineties have since then been characterized by growing inequality with higher wage dispersion at the lower end being most pronounced among workers with low tenure or entrants and low-skilled workers in West Germany. However, the expansion of Minijobs is responsible for increasing dispersion of gross wage whereas net wage appear relatively stable (figure 11). Wages for workers with longer tenure and those in firms covered by collective agreements are more rigid with adjustment taking place via reduction of employment or working hours (Gernandt/Pfeiffer 2006, Gerlach/Stephan 2005). However, this may have changed to some extent due to higher flexibility in collective agreements and unionized sectors as well. Relatively generous benefits, encapsulated segments of part-time low-wage jobs and reluctant activation still make it difficult to reintegrate the long-term unemployed into the regular labor market. It may also be difficult to reemploy workers made redundant in manufacturing where relative high wages could be earned. This is particularly problematic given high non-wage labor 
costs that are harmful to service sector employment (above Minijobs) with lower productivity.

--- insert figure 11 here ---

Therefore, the surplus in taxes and social insurance contributions generated by regular employment is not only spent on different schemes of passive labor market policies such as unemployment benefits and subsidized retirement, but also on the subsidization of different forms of low-wage employment that are no bridges to regular jobs but defined compartments. Dualization is not taking place through an expansion of fixed-term employment but through part-time employment, Minijobs and several forms of subsidized employment.

Neither was furthering low-wage entry jobs an explicit approach, nor were a broader flexibilization of the labor market and cuts in non-wage labor costs achieved which would have strengthened the job creation potential so that activation reforms could succeed. To reduce benefit dependency due to unemployment - and long-term unemployment in particular - and to create employment opportunities for workers made redundant in manufacturing, the service sector has to grow. But growth of service sector employment is still hampered due to problematic earnings thresholds and high nonwage labor costs. Because of the lack of stringent activation and strong disincentives against higher earnings or working time in the low-wage sector, benefit dependency of the long-term unemployed is still high. This strategy of partial labor market integration together with the unintended consequences of in-work benefits implies continuously high expenditures on labor market policies.

\section{The path of partial reforms}

German labor market reforms continued in the direction of a partial flexibilization of labor market regulation, distinct compartments of low-wage employment and a hesitant turn towards a more activating labor market policy. At the same time, however, the funding of the welfare state became increasingly more tax-based whereas social benefits break with the principle of status-protection and turn more and more into a basic protection regime.

Given the selective nature of flexibilization, the relative stability of the core labor market and only partial reductions in non-wage labor costs, the prospects for a more inclusive and permeable labor market more conducive to regular employment in the private service 
sector are mixed at best. Concession bargaining in manufacturing, however, has helped regain competitiveness and stabilize some of the employment there which is the backbone of the German employment regime and an essential source of welfare state funding. This path of partial and sometimes contradictory reforms, often correcting or revoking earlier reforms, has proven to be quite stable. Hence, the German labor market is neither entirely rigid nor has there been a comprehensive overhaul of the institutional setup. Despite the intense debate on Hartz and Agenda 2010, these reforms appear less impressive as they fit into the long-standing path of partial reforms.

Regarding the political logic of labor market reforms, we can still identify the effects of a relatively weak federal state with strong sectoral social partnerships and autonomy in wage setting, which are the historical features of the German political economy (Streeck/Hassel 2003, Busch 2005, Manow/Seils 2000). Stability in basic institutional features can be attributed to the relative incapacity of German governments to implement more long-term and comprehensive reform strategies (ZohInhöfer 2004a) and strong support of the institutional status quo by major groups in the electorate and organized interest. Hence, many aspects of the most recent reforms fit into a path of piecemeal reforms on a "middle way" which is highly probable given the strong consensus requirements in the political system.

This was both true not only for the phase of the ChristianDemocratic/Liberal coalition in power until 1998 which tried to implement partial 'liberal' reforms in the mid-nineties. Criticism of these reforms was formulated by the trade unions supporting the Social-Democratic electoral campaign in 1998, which resulted in an electoral victory and the reversal of most of these reforms. At the same time, however, the new red-green coalition tried to stabilize the established pattern of a highly regulated labor market and the social insurance system through stronger regulation of "precarious" employment and by trying to broaden the base for welfare state funding.

Thus, instead of implementing a strategy to "modernize" the German employment system, the Social Democrats initially adopted a more traditional approach. This was due to the perceived necessity to deliver on the electoral promises made vis-à-vis the trade union in exchange for their support. Through this initial approach to trade union-friendly reforms and parallel concessions in favor of the employers, i.e. the reform of corporate taxation, the German government could not stabilize the "Alliance for Jobs, Vocational Training and Competitiveness" which was initiated in late 1998 as a major arena for tripartite talks on a broader reform perspective on the labor market and the welfare state. Since government was neither 
willing nor capable of setting the agenda for the Alliance, this endeavor was immediately deadlocked despite attempts to create an elaborate institutional infrastructure (Streeck 2003, Streeck/Hassel 2003).

Further reform initiatives were postponed in favor of a "policy of the calm hand" until, in late 2001 and early 2002 economic activity slowed down substantially. The red-green government was confronted with rising unemployment and a weakened position in parliament due to a series of defeats in elections at the Federal State level. Hence, the scandal on placement statistics provided the Schröder government with a window of opportunity to regain the initiative in the employment issue. The Hartz Commission, installed on initiative of the Federal Chancellery, was a temporary expert committee that deviated from the model of tripartite or purely academic advice by comprising only few active politicians from the Federal State and municipal level, just two members from social partners and the academic sector and more professional business consultants and entrepreneurs. This facilitated overcoming the stalemate in labor market policy reform and helped breaking up social partner control in BA governance. The Hartz report also provided a blueprint for additional partial flexibilization of the labor market and a more activating approach to long-term unemployment. With this reform package, the Social Democrats could win the general election in fall 2005 and bind their hands as they promised a "1:1 implementation" of the Hartz recommendations (Dyson 2005). This helped neutralize potential opposition from the rank and file and the trade unions, which could also influence part of the actual legislation such as the re-regulation of TWA through collective agreements.

As many aspects of the Hartz proposal were only agreed upon at the price of lacking concreteness, the government had to push for additional clarification, e.g. regarding benefits for the long-term unemployed. Again under pressure due to rising unemployment, Schroeder announced the "Agenda 2010" in March 2003, a program with a clear focus on benefit cuts and further partial flexibilization of the labor market such as a rise in the threshold applicable to dismissal protection or a shortening of unemployment insurance benefits for older workers. It also stipulated that benefits for the longterm unemployed be flat-rate at the level of former social assistance. Agenda 2010 met strong resistance from the trade unions and the left wing of the Social Democrats in parliament. Public unrest was particularly pronounced in the East where losses from the abolishment of unemployment assistance were most prominent. It led to the foundation of a new left-wing party and electoral defeat of the red-green coalition in anticipated general elections in fall 2005.

The aftermath of the Hartz reforms and Agenda 2010 shows that a lack of a general societal consensus (Cox 2001) and a clear gov- 
ernment agenda on labor market reform can be considered the core explanation of both partial and contradictory reforms and electoral defeat of Schröder after a phase of more determined reform activities. As Agenda 2010 was in part inspired by the alleged "neoliberal" Schröder-Blair paper from 1999, which had met strong opposition at the time it was released, Schröder had risked a lot of his political capital when pushing for reforms. Yet, he could neither convince his own party nor the trade unions or the general public. This again points at the limited acceptance of more far-reaching reforms in Germany.

However, neither were the cutbacks through Hartz IV as harsh as expected, nor was activation as strict as originally announced. Hence, due to widespread fear of an "Americanization" of the German labor market, no clear concept for reintegration of the longterm unemployed and the low-skilled could be implemented. Hartz IV rather provided benefits close to or even exceeding low wages in the service sector, and activation could not be stringent given the problematic structure of implementation and limited acceptance of its basic principles by parts of the implementing actors. However, given the implicit in-work benefits, Hartz IV turned into a massive spending program with more and more people topping up low earnings through public resources. As benefit recipients, low-wage earners and employers quickly adapted to the new incentives in an unexpected way, the low wage sector was furthered through the backdoor, thus contributing to an "Americanized" segment of "working poor" who combine work and benefits. At the same time, the German system of in-work benefits creates new inactivity and poverty traps.

Without direct interference from government, which was reluctant to open up additional room to maneuver in legislation on collective agreements, e.g. through an explicit permission on enterprise-level deviations from industry-wide arrangements, the most recent developments in collective bargaining and firm-based "Alliances for Jobs", i.e. concessions with regard to wages and working time in exchange for employment guarantees, shows that market pressures lead to effective adjustments in manufacturing facing intense locational competition. Together with the slow erosion of bargaining coverage and union density, this means a loss of control by the trade unions but also by the employers' associations. Nevertheless, organized industrial relations are increasingly encapsulated in a shrinking segment of the labor market (Streeck/Hassel 2003). 


\section{Towards Better Adjustment?}

The adaptability of the German labor market is still limited: on the one hand, there is a dynamic but marginal segment of flexible jobs that offer only limited opportunities of upward wage mobility or transition to regular jobs. On the other hand, there is a declining core of the labor market with relatively high wages, jobs stability and social insurance. Recent developments in this part of the labor market, which is still covered by collective agreements, have made it more competitive and, therefore, more adaptable - however, this will not help ensure stability in a long-term perspective. Full labor market integration of the low-skilled and reemployment of workers made redundant is still unachieved, and both long-term unemployment and benefit dependency remain high which, in turn, implies continuity of high non-wage labor costs despite a partial shift to tax-based welfare state funding. Therefore, we might argue that the adjustment potential of the German labor market has only increased to a limited extent - with some of the additional flexibility encapsulated in particular segments of the labor market.

Notwithstanding intense public controversy and a high level of attention paid by foreign observers to labor market reforms in Germany, there still is a high level of path dependence, not only in terms of stability of core labor market institutions, but also with respect to the fact that with hindsight most of the reforms can be seen in the path dependency of partial reforms which has been characterizing the German employment systems for some time already. Piecemeal reforms, however, are insufficient regarding the creation of a more inclusive and permeable labor market and an institutional framework that is more conducive to growth in regular service employment beyond marginal jobs and several forms of subsidized employment.

Hence, the risk of slow asphyxiation of the regular labor market with socially insured employment relationships persists. This is most apparent in the decline of regular employment, whereas flexible jobs grow. Social security payments to the unemployed, the inactive and early retirees hamper job creation and thus employment opportunities, particularly in the service sector. Attempts at stabilizing the core of the labor market make the employment system less permeable and segment the labor market to the detriment of women, lowskilled and older workers, groups which have only limited access to employment, i.e. labor market entry and reentry, and upward mobility in a system that is still rather selective. However, financing inactivity and limited access to employment is quite expensive in terms of social benefits and subsidized (non)employment, which means two things: 
First, compensation by passive benefits crowds out public resources which could be invested in early childhood care, education and training in order to improve human capital, productivity and capacities to innovate - factors that would stimulate long-term economic growth and prevent benefit dependency due to lack of skills. Present passive social and labor market policies might therefore lead to lower growth and less societal welfare in the future.

Second, high benefit dependency means higher taxes and social security contributions for average earners. This, in turn, increases the pressure to raise productivity and downsize regular employment, last but not least in traditional and highly unionized manufacturing. High taxes and social security contributions may also erode support for the welfare state as in phases of wage moderation this means stagnating or declining net wages. Hence, one might argue that the growth of flexible employment and a growing tax burden might generate support for more employment-oriented reforms that reduce benefit dependency and raise labor force participation.

A more coherent strategy in favor of stronger employment growth in the service sector would mean higher inequality in the labor market as average earnings in the service sector would be lower, particularly in jobs that would be realistic entry opportunities for longterm unemployed and low-skilled workers. Hence, this implies questioning the current low activity/low inequality regime and the established level of social benefits. Given both the problematic acceptance of Hartz IV and more market-oriented reforms that would result in higher earnings inequality and the prominence of "social justice" considerations in political discourse, it is still unclear which level of inequality in the labor market and redistribution via taxes and benefits will be acceptable in Germany. Hence, Germany finds itself between the two real models of more inclusive labor markets the Scandinavian tax-based welfare state with high public employment on the one hand, the Anglo-Saxon regime with strong private service sector expansion, high inequality and strong activation via workfare and in-work benefits (Scharpf 1997). And neither model is feasible in the German political economy.

The grand coalition formed by Christian Democrats and Social Democrats in November 2005 reflects this ambivalent attitude towards more fundamental reforms quite nicely. The general elections of September 2005 made it clear that there is no mandate for reforms as the Christian Democrats did not receive a majority for their more far reaching reform announcements, whereas the Social Democrats, who had suffered from intense internal struggles and public disapproval in 2004 and early 2005, could reach almost the same amount of votes as the Christian Democrats with a more "social" profile in the electoral campaign. This shows that there is no broad societal consensus on the direction of labor market and welfare 
state reforms, and both major parties in power are now internally divided on this issue. Although the grand coalition does not have to fear opposition in the first or the second chamber of parliament, its policy profile is characterized by the well-known ambivalence towards labor market and welfare state reforms. Both parties have also learned that more "cruel" reforms will not be supported by the electorate. Hence, the new government continues on the path of piecemeal and sometimes contradictory reforms. However, announced reforms also seem more "social democratic" than in the second half of the Schröder government.

This can be seen from increasing the tax-share in welfare state funding that will result form the VAT increase in 2007. In exchange, contributions to unemployment insurance shall be reduced. Additional economies in the contribution-funded part of active labor market policies will also help reduce the burden of non-wage labor costs. However, the most recent compromise regarding health care funding will only lead to the creation of a partially tax-based health care fund in the medium term whereas in 2007 contributions to health insurance, but also to old-age pension insurance, will be raised. This increase will probably offset the reduction in unemployment insurance contributions and fits into the path of fiscal short-term stabilization. A substantial reduction of non-wage labor cost is not foreseeable.

At the same time, activation of the long-term unemployed under Hartz IV is modified stressing the more demanding elements in order to avoid further extra expenditure there. However, an effective organization of reintegration services and funding is still lacking as is a consistent strategy towards reentry into the labor market via low-wage jobs. On the one hand, some actors consider expanding in-work benefits without cuts in benefits which would result in even more pronounced part-time incentives and fiscal risks, whereas others advocate statutory or generally binding minimum wages in order to restrict wage dispersion and avoid a fall in wages to the detriment of the public budget and collectively agreed wage scales although this might hamper reintegration of the low-skilled and longterm unemployed. Yet, the question how to reduce benefit dependency and to strengthen job creation in the service sector and reemployment of the low-skilled is still unanswered. On the other hand, however, the grand coalition could reduce some tax exemptions and raise the statutory retirement age from 65 to 67 , but incentives for later exit from the labor market are still weak, as other instruments such as old-age part-time work and benefit receipt without being available for work were prolonged. Labor market regulation will eventually see reform with fixed-term employment without specified reason being replaced by a general probationary period of two years. 
Given this ambiguous policy outline, we will most probably see another protracted series of partial reforms in the nearer future that will add some flexibility to the German labor market but will not result in a sustainable solution to Germany's employment problems. 
Annex: Tables and Charts

Figure 1: unemployment and employment rates, 1994-2005

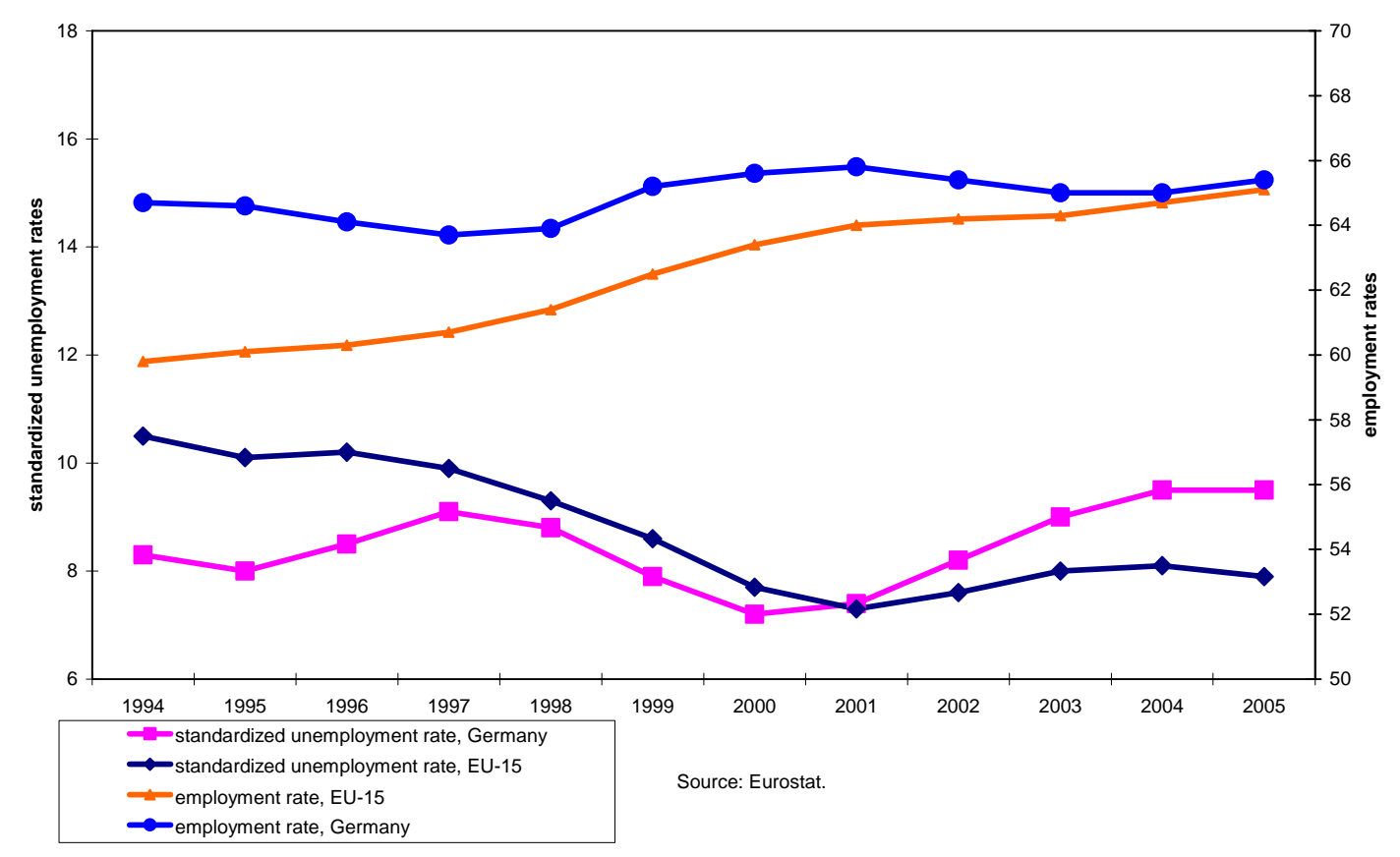

Figure 2: Social Security Contribution Rates in \% of Gross Wages, 1990-2005

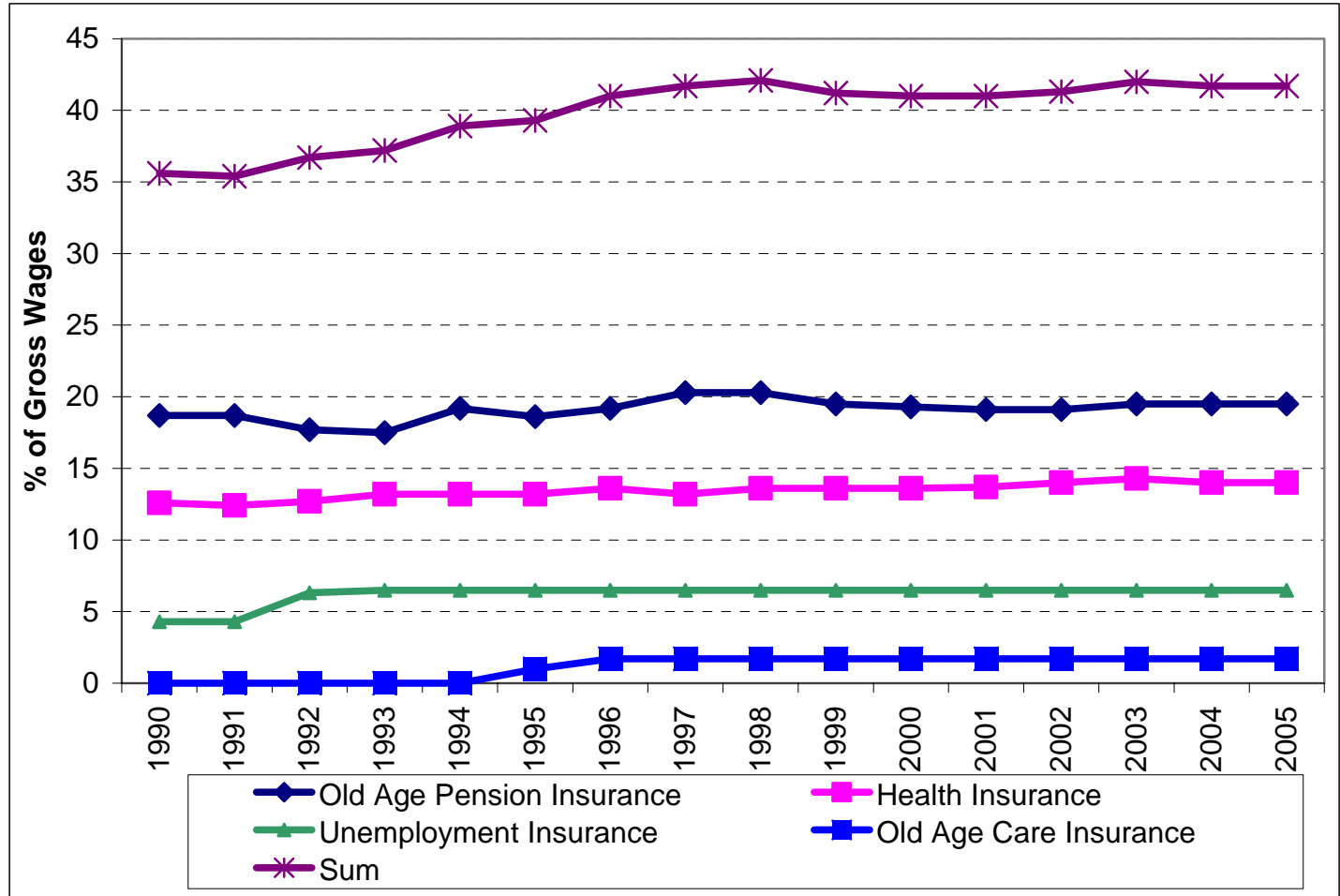

Source: Federal Ministry of Health. 
Figure 3: Employment growth and total hours worked, $1992=100$

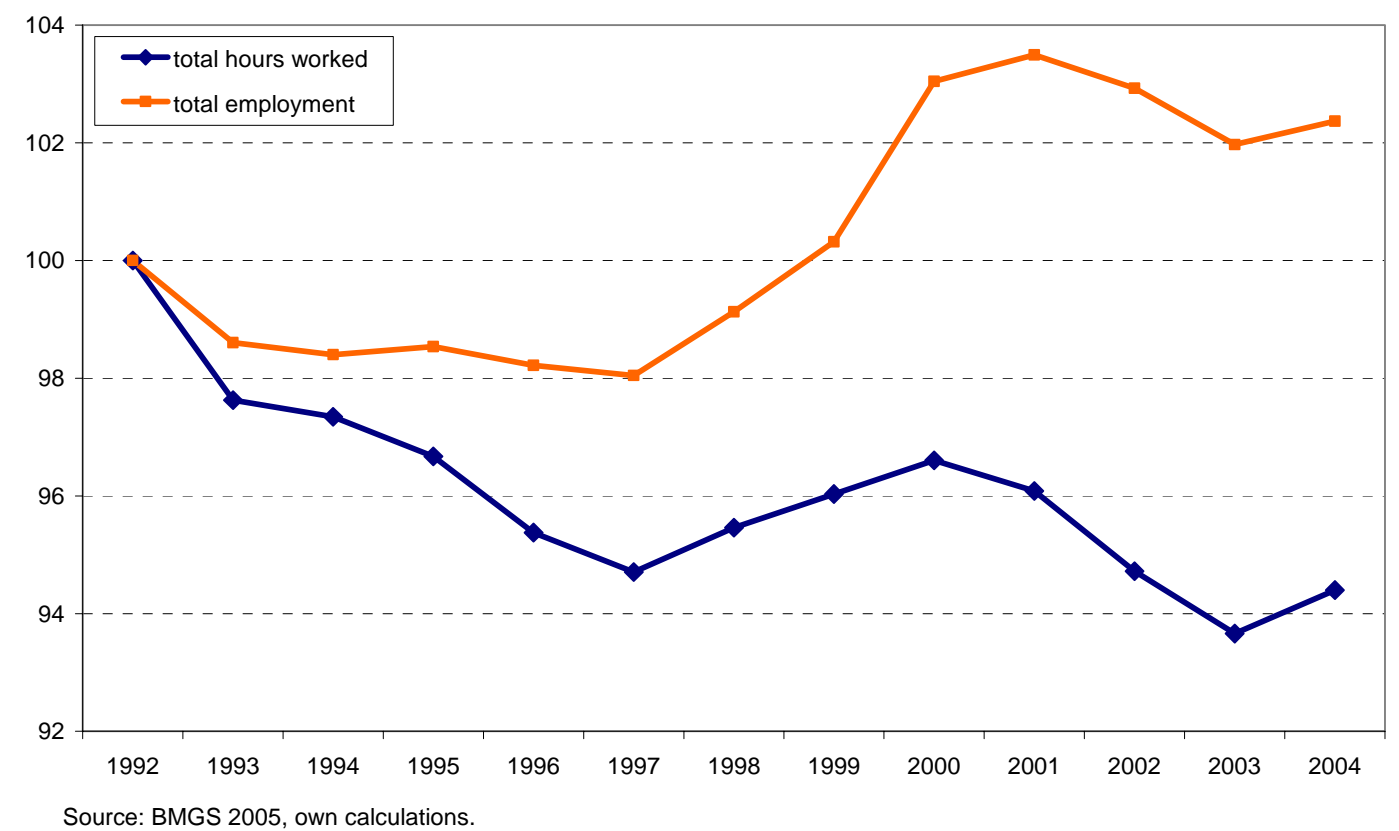

Figure 4: Differentials in employment/ population ratios by gender, age and qualification, 1994 and 2004

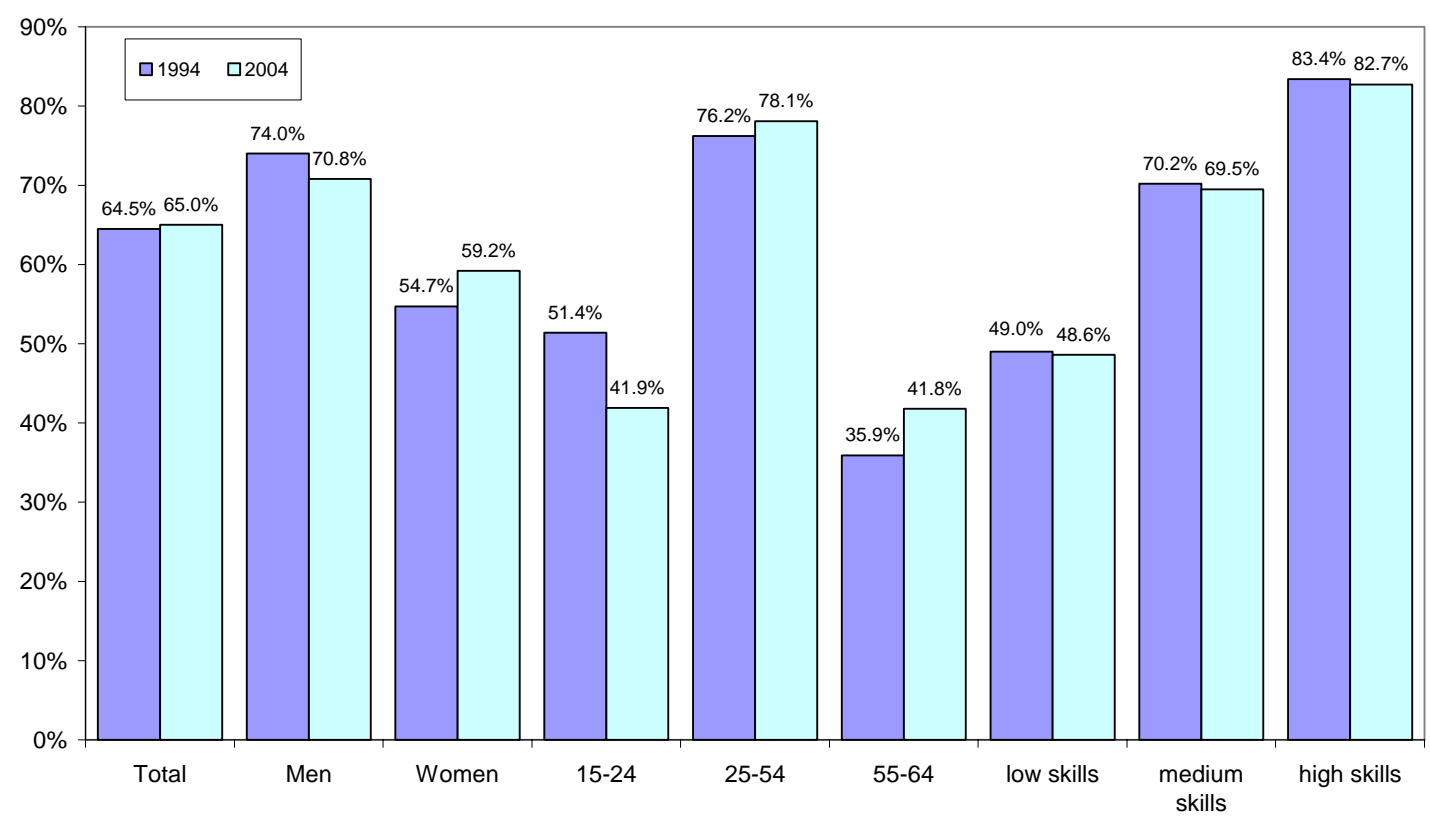

Source: OECD Employment Outlook, various 
Figure 5: Employment by sector, millions, 1992-2004

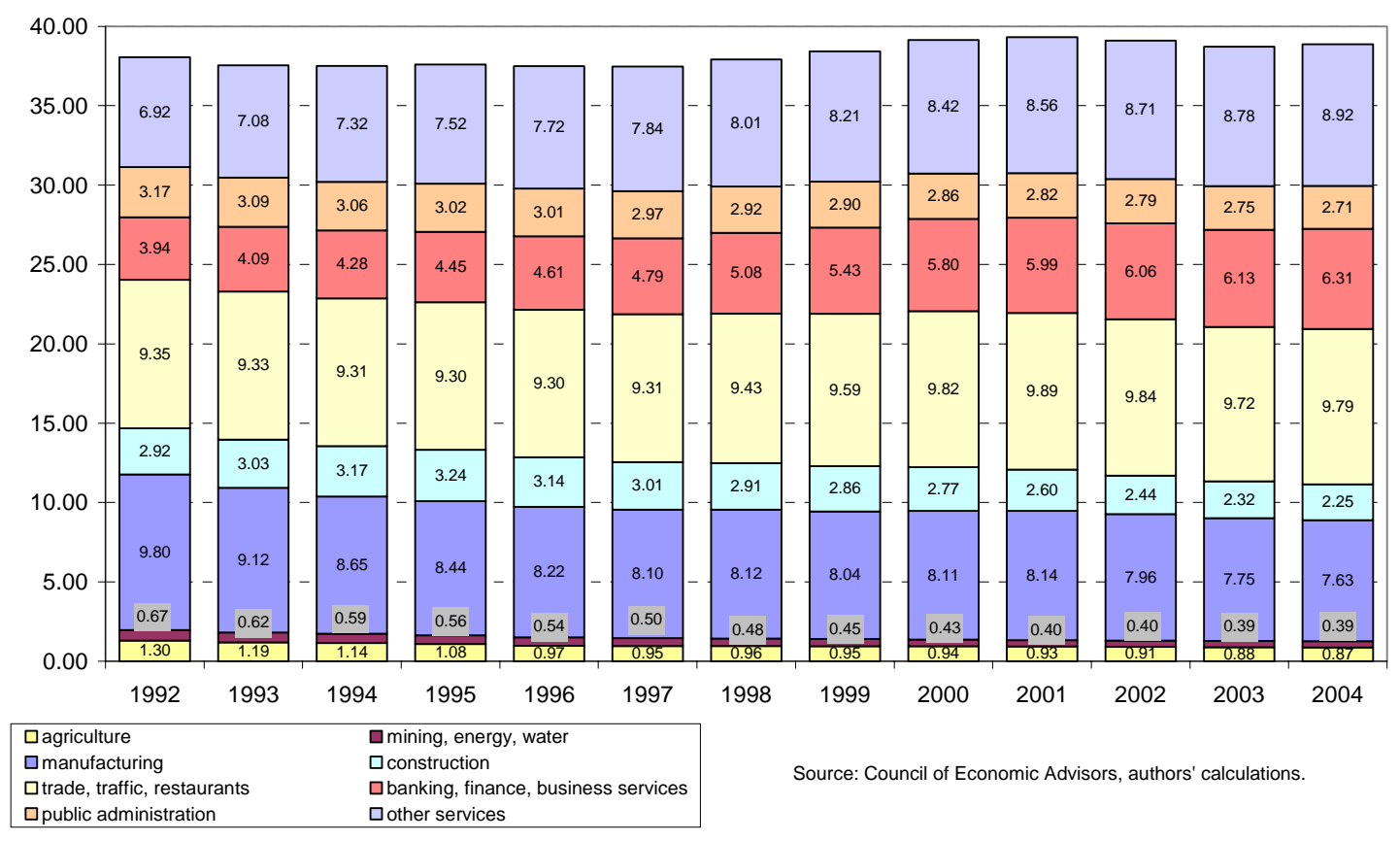

Figure 6: Regular and flexible employment in \% of total employment, 1992-2004

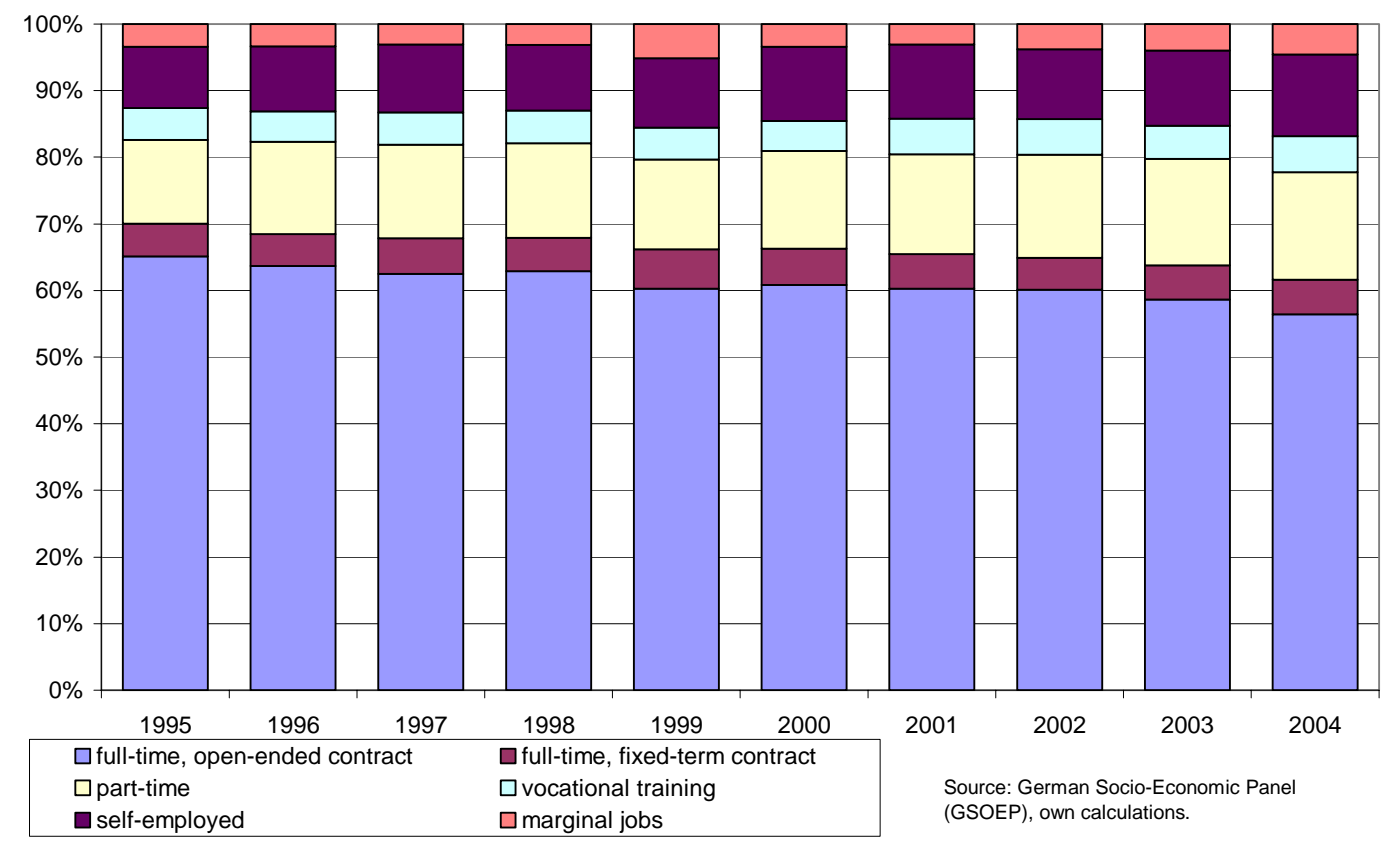


Figure 7: Regular employment covered by social insurance, Minijobs and second jobs, 1999-2006

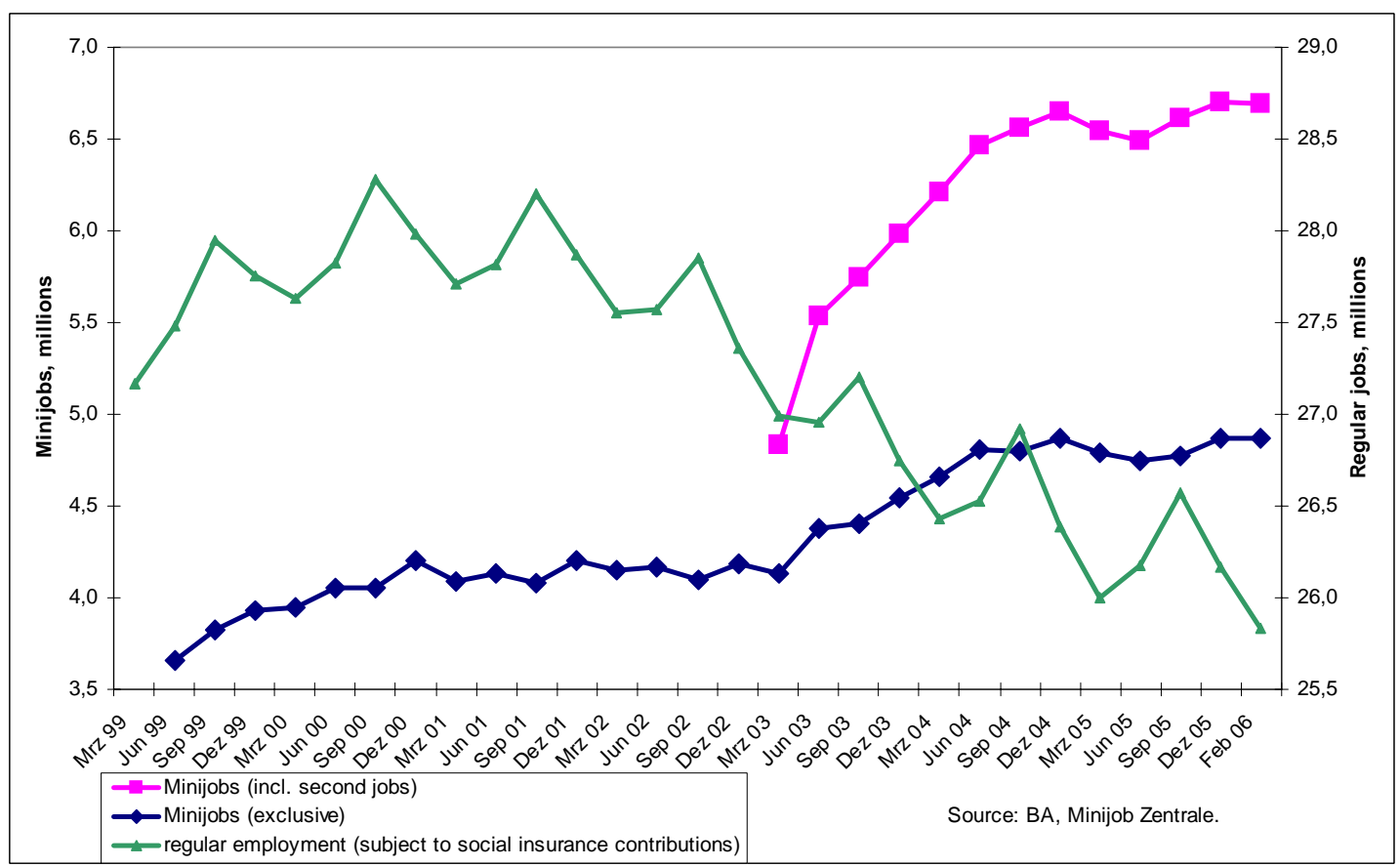

Figure 8: Stocks of participants in major labor market policy schemes before and after the Hartz reforms

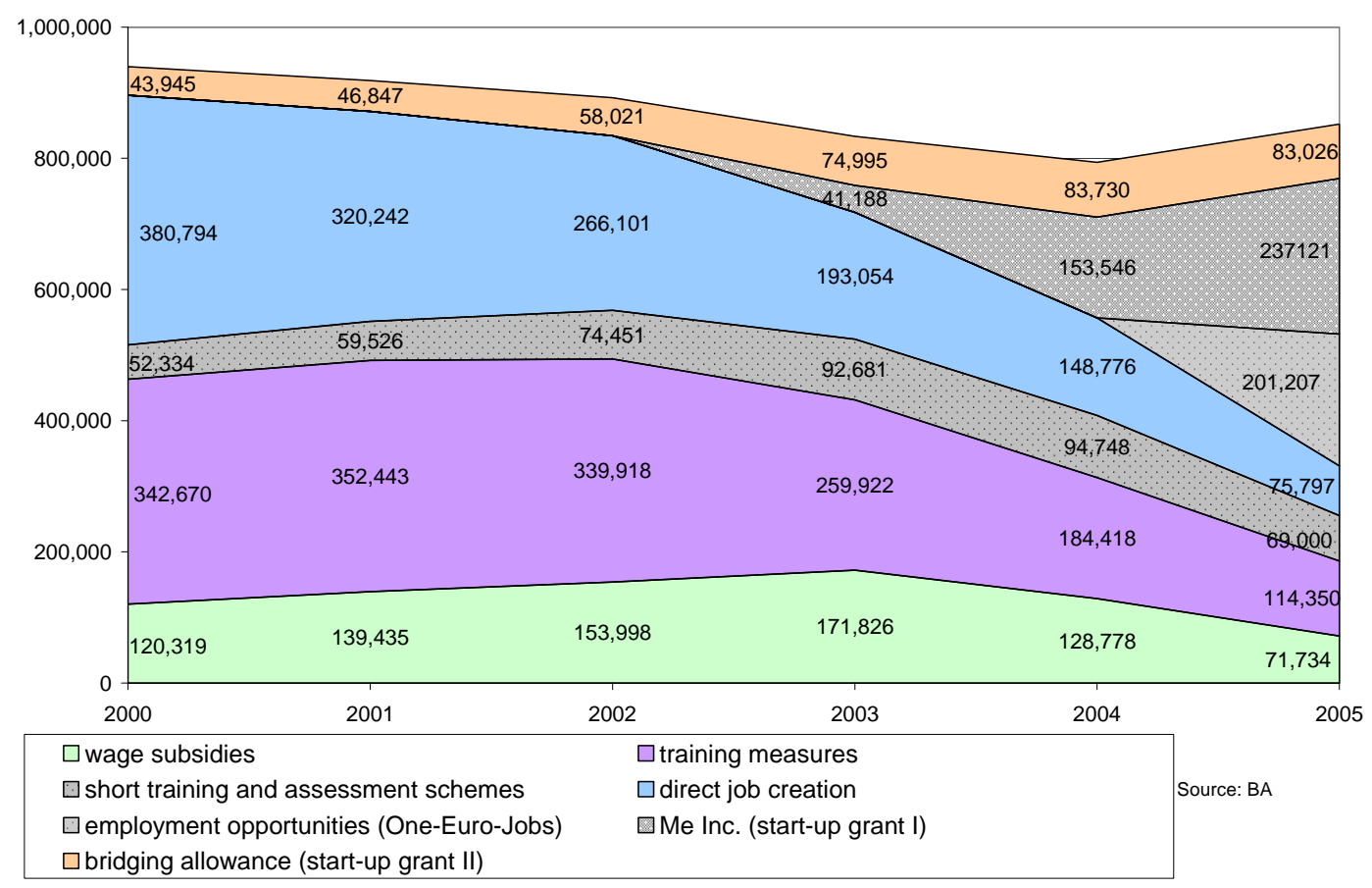


Figure 9: Registered and hidden unemployment, 1998-2006

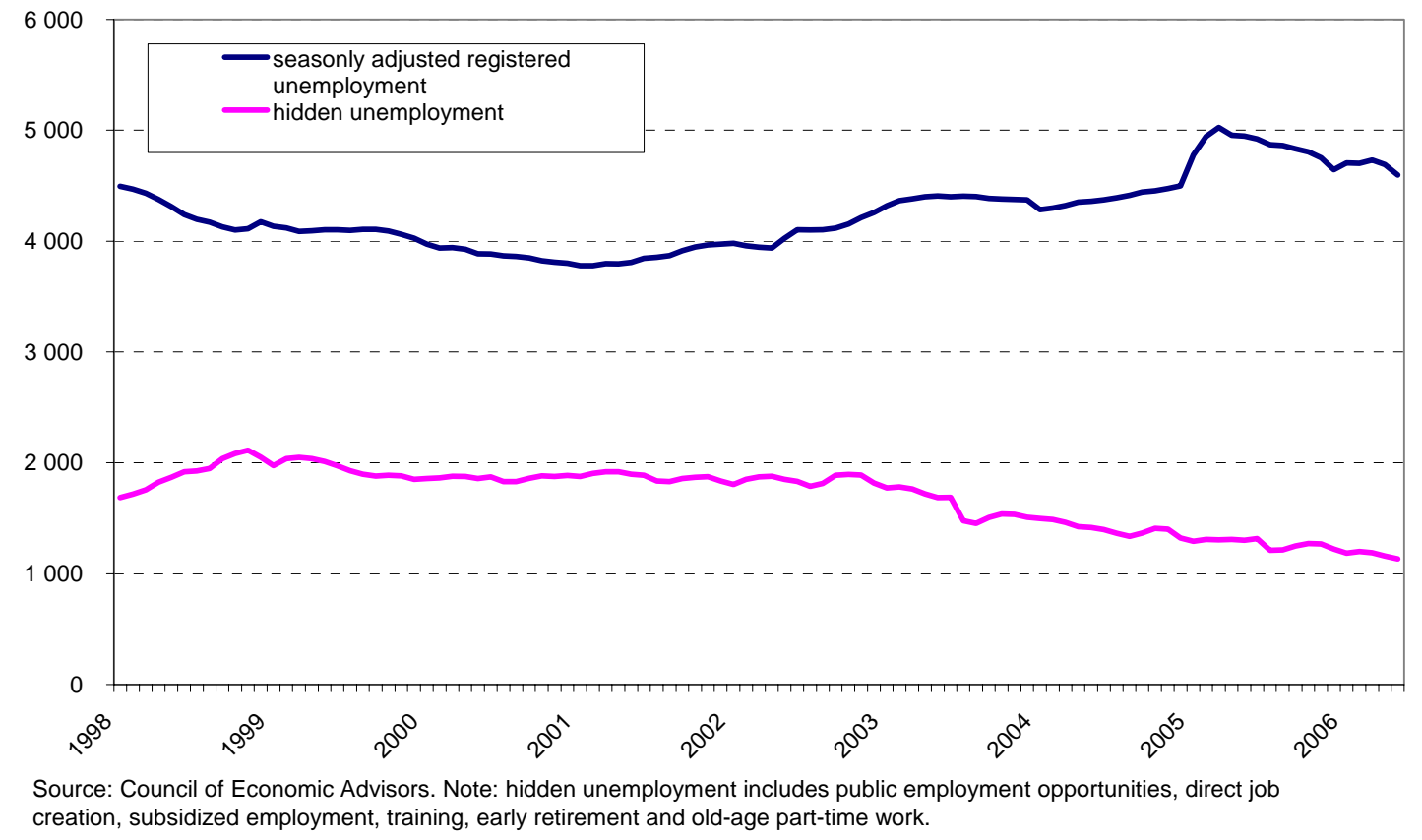

Figure 10: Estimated and actual numbers of recipients of unemployment assistance (pre/ post Hartz IV)

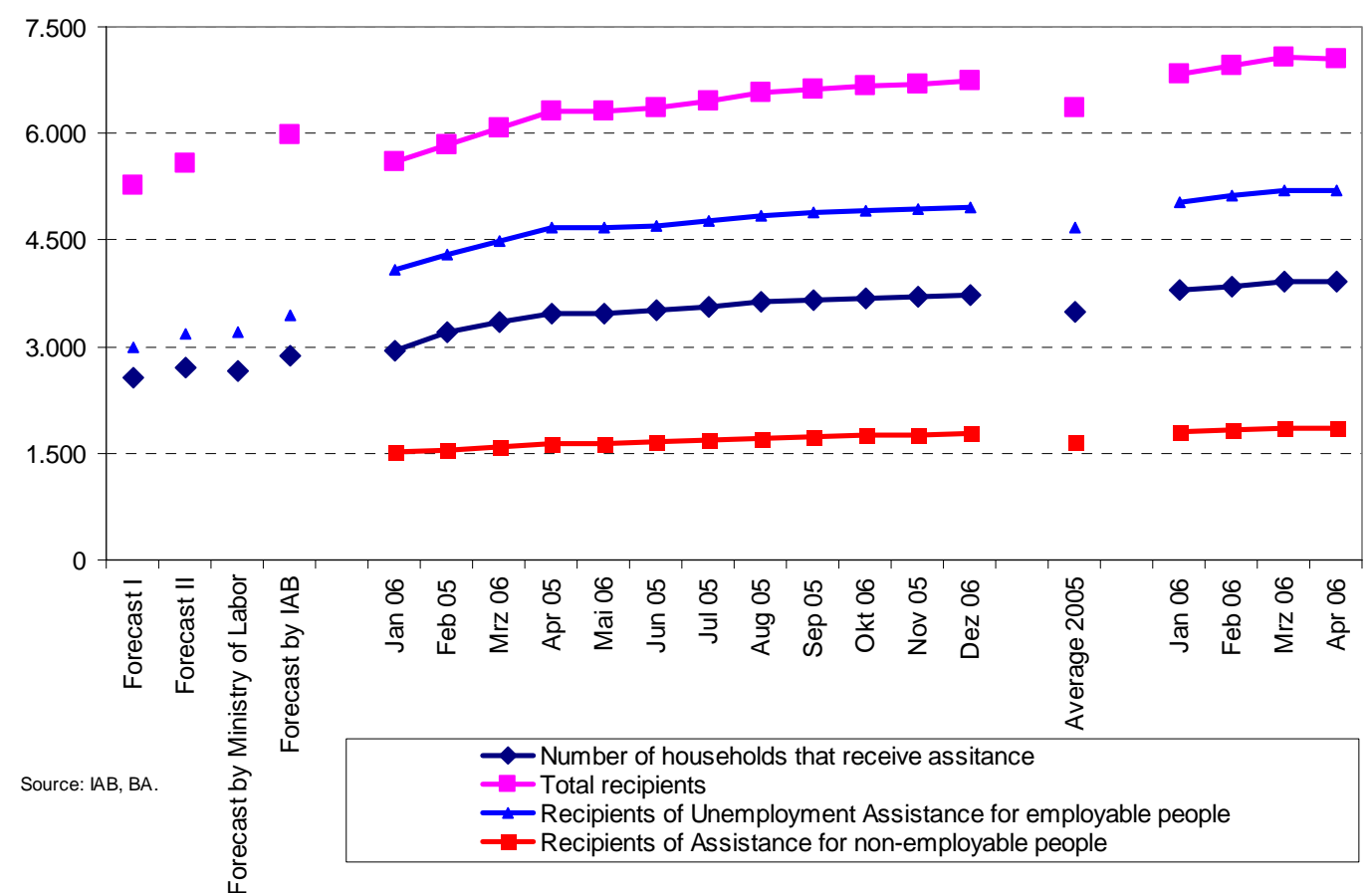


Figure 11: Low-wage employment in \% of total employment, gross and net wages

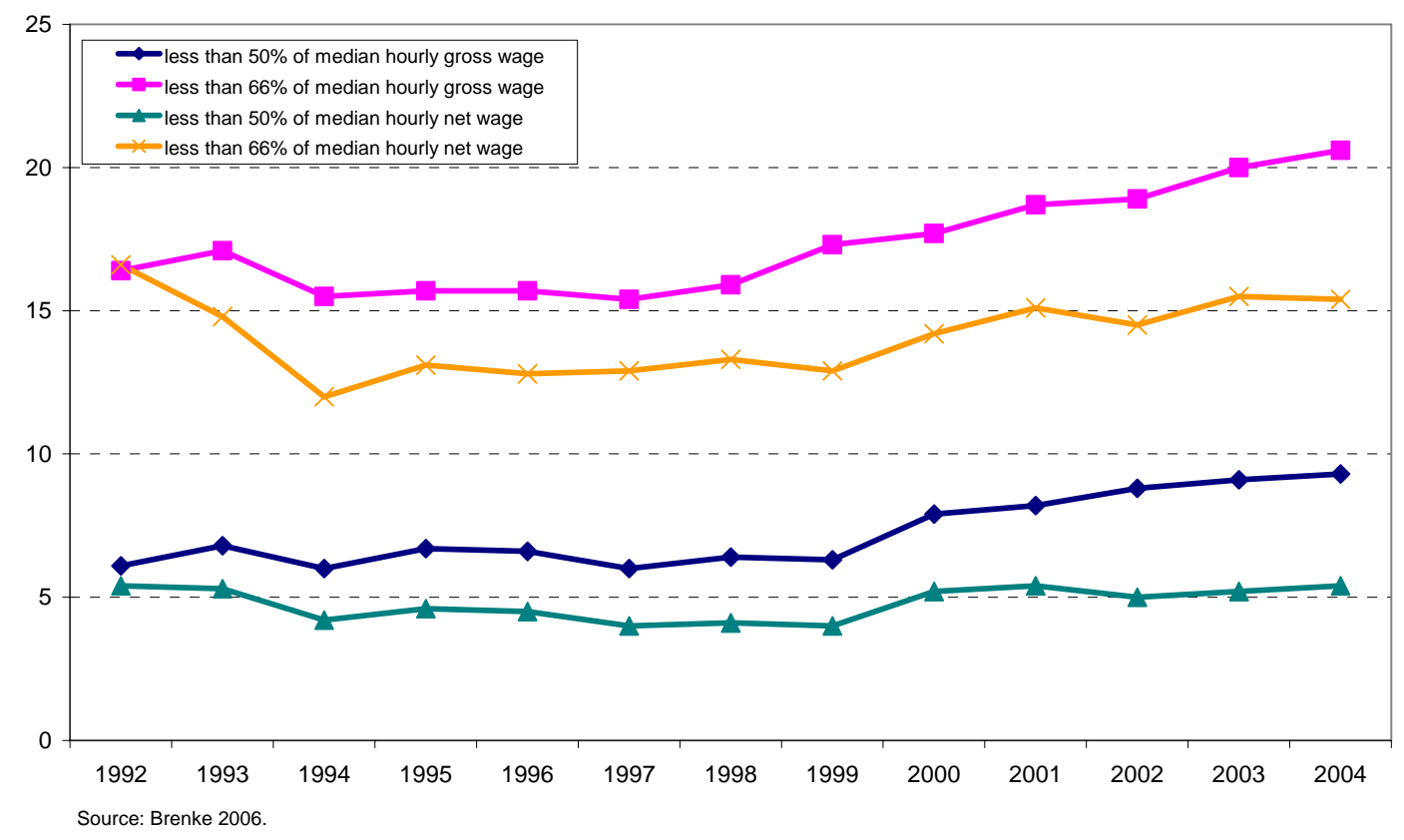

Table 1: Unemployment Assistance and market wages

\begin{tabular}{|c|c|c|c|c|c|c|}
\hline \multicolumn{7}{|c|}{ Arbeitslosengeld II, public employment opportunities and equivalent market wages } \\
\hline & \multirow{2}{*}{$\begin{array}{c}\text { Net benefits from } \\
\text { Arbeitslosengeld II + } \\
\text { social assistance for } \\
\text { non-employable } \\
\text { members of } \\
\text { household + } \\
\text { housing/heating } \\
\text { benefit (+ temporary } \\
\text { supplement) }\end{array}$} & \multicolumn{2}{|c|}{ equivalent wages } & \multirow{2}{*}{$\begin{array}{c}\text { Arbeitslo- } \\
\text { sengeld II } \\
+ \text { compen- } \\
\text { sation for } \\
\text { public } \\
\text { employment } \\
\text { opportunity } \\
\text { of } € 1.50 \text { at } 30 \\
h \text { per week }\end{array}$} & \multicolumn{2}{|c|}{$\begin{array}{c}\text { equivalent } \\
\text { wages }\end{array}$} \\
\hline & & $\begin{array}{c}\text { net hourly } \\
\text { wage (40 h } \\
\text { per week) }\end{array}$ & $\begin{array}{c}\text { gross } \\
\text { hourly } \\
\text { wage } \\
(40 \mathrm{~h} \\
\text { per } \\
\text { week) }\end{array}$ & & $\begin{array}{c}\text { net } \\
\text { hourly } \\
\text { wage } \\
\text { (40 h } \\
\text { per } \\
\text { week) }\end{array}$ & $\begin{array}{c}\text { gross } \\
\text { hourly } \\
\text { wage } \\
(40 \mathrm{~h} \\
\text { per } \\
\text { week) }\end{array}$ \\
\hline & \multicolumn{6}{|c|}{ in $€$} \\
\hline Single & $662-822$ & $\begin{array}{c}3.10- \\
4.40\end{array}$ & $\begin{array}{l}3.70- \\
5.65\end{array}$ & $857-1017$ & $\begin{array}{l}4.70- \\
5.90\end{array}$ & $\begin{array}{c}6.10- \\
8.10\end{array}$ \\
\hline $\begin{array}{l}\text { Single parent, } \\
\text { one child }\end{array}$ & $1090-1310$ & $\begin{array}{c}3.35- \\
4.95\end{array}$ & $\begin{array}{c}4.20- \\
6.30\end{array}$ & $1285-1505$ & $\begin{array}{l}4.75- \\
7.00\end{array}$ & $\begin{array}{c}5.95- \\
9.95\end{array}$ \\
\hline $\begin{array}{l}\text { Married, single } \\
\text { earner }\end{array}$ & $1034-1354$ & $\begin{array}{l}5.65- \\
7.80\end{array}$ & $\begin{array}{l}7.10- \\
9.80\end{array}$ & $1229-1549$ & $\begin{array}{l}7.10- \\
8.95\end{array}$ & $\begin{array}{l}8.90- \\
11.50\end{array}$ \\
\hline $\begin{array}{l}\text { Married, single } \\
\text { earner, two } \\
\text { children }\end{array}$ & $1574-2014$ & $\begin{array}{c}3.80- \\
7.35\end{array}$ & $\begin{array}{c}4.80- \\
9.25\end{array}$ & $1769-2209$ & $\begin{array}{c}5.30- \\
8.55\end{array}$ & $\begin{array}{l}6.35- \\
10.90\end{array}$ \\
\hline
\end{tabular}

Net hourly wages include child benefit, child supplement for low-wage earners and housing benefit. Source: IAB (Cichorek/Koch/Walwei 2005). 


\section{References}

Boockmann, Bernhard/Hagen, Tobias (2005): Befristete und andere „atypische“ Beschäftigungsverhältnisse: wird der Arbeitsmarkt funktionsfähiger? In: Zeitschrift für Arbeitsmarktforschung 38 (2-3), 305-324.

Boss, Alfred/Christensen, Björn/Schrader, Klaus (2005): Anreizprobleme bei Hartz IV: lieber ALG II statt Arbeit? Kieler Diskussionsbeiträge 421. Kiel: IfW.

Brandt, Nicola/Burniaux, Jean-Marc/Duval, Romain (2005): Assessing the OECD Jobs Strategy: Past developments and reforms. OECD Economics Department Working Paper 429. Paris: OECD.

Brenke, Karl (2006): Wachsender Niedriglohnsektor in Deutschland - sind Mindestlöhne sinnvoll? DIW Wochenbericht 15-16/2006. Berlin: DIW.

Bundesministerium für Gesundheit und Soziale Sicherung (2005): Statistisches Taschenbuch 2005. Berlin: BMGS.

Bundesregierung (2006): Die Wirksamkeit moderner Dienstleistungen am Arbeitsmarkt. Bericht 2005 der Bundesregierung zur Wirkung der Umsetzung der Vorschläge der Kommission Moderne Dienstleistungen am Arbeitsmarkt. Berlin: BMAS.

Büttner, Renate (2005): Zunehmende Erwerbsbeteiligung von Älteren. IAT Altersübergangsreport 2005-04. Gelsenkirchen: IAT.

Christensen, Björn (2005): Die Lohnansprüche deutscher Arbeitsloser Determinanten und Auswirkungen von Reservationslöhnen. Berlin: Springer.

Cichorek, Anne/Koch, Susanne/Walwei, Ulrich (2005): Arbeitslosengeld II: Erschweren „Zusatzjobs“ die Aufnahme einer regulären Beschäftigung? das Gesamteinkommen von ALG II-Empfängern in einer Arbeitsgelegenheit bewegt sich nahe der Niedriglohnschwelle. IAB Kurzbericht 8/2005. Nürnberg: IAB.

Cox, Robert H. (2001): The Construction of an Imperative: Why Welfare Reform Happened in Denmark and the Netherlands but Not in Germany. In: World Politics 53 (3) 2001, 463-498.

Deutscher Industrie- und Handelskammertag (2004): Individuell und flexibel - Wettbewerbsfaktor Arbeitszeitgestaltung. Ergebnisse einer DIHKUnternehmensbefragung Herbst 2004. Berlin: DIHK.

Dyson, Kenneth (2005): Authoritative and Reflexive Strategies for Binding Hands: Europeanization, Government by Commission, and Economic Reform. In: German Politics 14 (2), 224-247.

Ebbinghaus, Bernhard/Hassel, Anke (2000): Striking Deals: The Role of Concertation in the Reform of the Welfare State. In: J ournal of European Public Policy 7 (1) 2000, 44-62.

The Economist (2005): Germany's surprising economy, 18.08.2005.

The Economist (2006): Waiting for a Wunder, 09.02.2006. 
Eichhorst, Werner (2006): Beschäftigung Älterer in Deutschland: Der unvollständige Paradigmenwechsel. In: Zeitschrift für Sozialreform 52 (1), 101-123.

Eichhorst, Werner/Profit, Stefan/Thode, Eric (2001): Benchmarking Deutschland: Arbeitsmarkt und Beschäftigung. Berlin: Springer.

Eichhorst, Werner/Konle-Seidl, Regina (2005): The Interaction of Labor Market Regulation and Labor Market Policies in Welfare State Reform, IZA Discussion Paper 1718. Bonn: IZA.

Eichhorst, Werner/Zimmermann, Klaus F. (2005): Eine Bilanz der rotgrünen Wirtschafts- und Beschäftigungspolitik. In: Aus Politik und Zeitgeschichte B 43, 11-17.

Eichhorst, Werner/Zimmermann, Klaus F. (2006): Durchmarsch oder Richtungswechsel in der Beschäftigungspolitik? In: Wirtschaftsdienst 86 (7).

Erlinghagen, Marcel/Knuth, Matthias (2004): In Search of Turbulence. Labour Market Mobility and J ob Stability in Germany. In: European Societies 6 (1) 2004, 49-70.

Esping-Andersen, Gøsta (1990): The Three Worlds of Welfare Capitalism Cambridge: Polity Press.

Esping-Andersen, Gøsta (1996): Welfare States Without Work: the Impasse of Labour Shedding and Familialism in Continental European Social Policy. In: Esping-Andersen, Gøsta (Ed.): Welfare States in Transition. National Adaptations in Global Economies. London: Sage, 66-87.

Esping-Andersen, Gøsta/Regini, Marino (Eds.) (2000): Why Deregulate Labour Markets? Oxford: Oxford University Press.

Estevez-Abe, Margarita/Iversen, Torben/Soskice, David (2001): Social Protection and the Formation of Skills. In: Hall, Peter A./Soskice, David (Eds.): Varieties of Capitalism: The Institutional Foundations of Comparative Advantage. Oxford: Oxford University Press, 145-183.

Gerlach, Knut/Stephan, Gesine (2005): Wage Distribution by WageSetting Regime. IAB Discussion Paper 9/2005. Nürnberg: IAB.

Gernandt, J ohannes/Pfeiffer, Friedhelm (2006): Rising Wage Inequality in Germany. ZEW Discussion Paper 05-26. Mannheim: ZEW.

Hall, Peter A./Soskice, David Soskice (2001): An Introduction to Varieties of Capitalism. S. 1-68. In: Hall, Peter A./Soskice, David (Eds.): Varieties of Capitalism: The Institutional Foundations of Comparative Advantage. Oxford: Oxford University Press, 1-68.

Hoffmann, Edeltraud/Walwei, Ulrich (2003): The change in work arrangements in Denmark and Germany: erosion or renaissance of standards? In: Houseman. Susan/Osawa, Machiko (Eds.), Nonstandard work in developed economies: causes and consequences, Kalamazoo: Upjohn Institute for Employment Research, 15-52.

Jacobi, Lena/Kluve, Jochen (2006): Before and After the Hartz Reforms: The Performance of Active Labour Market Policy in Germany. IZA Discussion Paper 2100. Bonn: IZA. 
Jahn, Elke J. (2005): Wie wirkt der Kündigungsschutz? In: Zeitschrift für Arbeitsmarktforschung 38 (2-3), 284-304.

Kaiser, Lutz C./Rinne, Ulf/Schneider, Hilmar (2006): Costs and Benefits of Publicly Financed Training in Germany. mimeo. Bonn: IZA.

Kalina, Thorsten/Weinkopf, Claudia (2006): Mindestens sechs Millionen Niedriglohnbeschäftigte in Deutschland: Welche Rolle spielen Teilzeitbeschäftigte und Minijobs? IAT-Report 3/2006. Gelsenkirchen: IAT.

Kaltenborn, Bruno/Schiwarov, Juliana (2006): Hartz IV: Ausgaben deutlich unterschätzt. Blickpunkt Arbeit und Wirtschaft 6/2006. Berlin.

Kemmerling, Achim/Bruttel, Oliver (2005): New politics in German labour market policy? The implications of the recent Hartz reforms for the German welfare state. WZB Discussion Paper 2005-101. Berlin: WZB.

Manow, Philip/Seils, Eric (2000): Adjusting Badly: The German Welfare State, Structural Change, and the Open Economy. In: Scharpf, Fritz W./Schmidt, Vivien A. (Eds.): Welfare and Work in the Open Economy, Vol 2. Oxford: Oxford University Press, 264-307.

OECD (2004a): OECD Employment Outlook. Paris: OECD.

OECD (2004b): Economic Surveys: Germany. Paris: OECD.

OECD (2005a): Taxing Wages. Paris: OECD.

OECD (2005b): Ageing and Employment Policy: Germany. Paris: OECD

OECD (2006a): Economic Surveys: Germany. Paris: OECD.

OECD (2006b): OECD Employment Outlook. Paris: OECD.

Orszag, Michael/Snower, Dennis J. (1998): Anatomy of Policy Complementarities. In: Swedish Economic Policy Review 5 (2), 303-343.

Oschmiansky, Frank/Müller, Kai-Uwe (2005): Die Sanktionspolitik der Arbeitsagenturen: Eine empirische Analyse zu Sperrzeiten. In: Schütz, Holger/Mosley, Hugh (Eds.), Arbeitsagenturen auf dem Prüfstand - Leistungsvergleich und Reformpraxis der Arbeitsvermittlung. Berlin: Edition Sigma, 95-134.

Pierson, Paul (2000): Increasing Returns, Path Dependence, and the Study of Politics. American Political Science Review 94 (2), 251-268.

Rehder, Britta (2003): Betriebliche Bündnisse für Arbeit in Deutschland. Frankfurt: Campus.

Rhein, Thomas/Gartner, Hermann/Krug, Gerhard (2005): Niedriglohnsektor: Aufstiegschancen für Geringverdiener verschlechtert. IAB Kurzbericht 3/2005. Nürnberg: IAB.

Scharpf, Fritz W. (1997): Employment and the Welfare State. A Continental Dilemma. MPIfG Working Paper 97/7. Köln: Max Planck Institute for the Study of Societies.

Scharpf, Fritz W. (2000): Economic Changes, Vulnerabilities, and Institutional Capabilities. In: Scharpf, Fritz W./Schmidt, Vivien A. (Eds.), Welfare and Work in the Open Economy. Vol.1: From Vulnerability to Competitiveness. Oxford: Oxford University Press, 21-124. 
Schmidt, Manfred G. (2002): Germany: The Grand Coalition State. In: CoIomer, Josep. M. (Ed.): Political Institutions in Europe. London: Routledge, 2. ed., 55-93.

Schmidt, Manfred G. (2001): Still on the Middle Way? Germany's Political Economy at the Beginning of the Twenty-First Century, in: German Politics 10 (3), 1-12.

Schnabel, Claus (2005): Gewerkschaften und Arbeitgeberverbände: Organisationsgrade, Tarifbindung und Einflüsse auf Löhne und Beschäftigung. In: Zeitschrift für Arbeitsmarktforschung 38 (2-3), 181-196.

Schröder, Gerhard/Blair, Tony (1999): Der Weg nach vorne für Europas Sozialdemokraten. London, 8. Juni 1999.

Steffen, Johannes (2006): Sozialpolitische Chronik. Bremen: Arbeitnehmerkammer.

Streeck, Wolfgang (1997): German Capitalism: Does It Exist? Can It Survive?, in: C. Crouch, Colin/Streeck, Wolfgang (Eds.), Political Economy of Modern Capitalism: Mapping Convergence and Diversity. London: Sage, 33-54.

Streeck, Wolfgang (2003): No Longer the Century of Corporatism. Das Ende des "Bündnisses für Arbeit". MPIfG Working Paper 03/4. Köln: MPIfG.

Streeck, Wolfgang/Hassel, Anke (2003): The Crumbling Pillars of Social Partnership. In: West European Politics 26 (4), 101-124.

Streeck, Wolfgang/Trampusch, Christine (2005): Economic Reform and the Political Economy of the German Welfare State. In: German Politics 14 (2), 174-195.

Zohlnhöfer, Reimut (2004a): Destination Anywhere? The German RedGreen Government's Inconclusive Search for a Third Way in Economic Policy, in: German Politics 13 (1) March 2004, 106-131.

ZohInhöfer, Reimut (2004b): Die Wirtschaftspolitik der rot-grünen Koalition: Ende des Reformstaus? In: Zeitschrift für Politikwissenschaft 14 (2), 381-402. 